\title{
THE HAND OF LAW AND THE BODY OF FAMILY. FAMILY, FEAR AND THE COURT OF LAW IN QING CHINA
}

\author{
Asia Alyevna Sarakaeva \\ Hainan University. Haikou, China. Email: asia-lin[at]mail.ru
}

\begin{abstract}
The article, through the lens of crimes and court cases, explores the complex relationship between the individual, family and state in China in the XVII-XIX centuries. The research is based on archival court cases and fiction literature of traditional China. The author examines crimes committed within the family, analyses the testimony of criminals and witnesses, as well as sentences and government decrees; compares the real transcripts of court hearings with the depiction of family conflicts, investigations and trials in adventure novels and short stories by Chinese writers. As a result, the author comes to a number of conclusions, in particular, that the Qing government gradually shifted the emphasis from the value of filial piety and generational hierarchy to the special importance of marriage relations; while in public mindset, on the contrary, the inertia of Confucianism and the desire to protect the integrity and autonomy of the family body from interference by state power were extremely strong. Speaking about the reaction of the Chinese family to the crime that occurred within its ranks, the author identifies several typical ways of responding, with the choice of method being often determined by the gender of the conflicting parties.
\end{abstract}

\section{Keywords}

China; Qing dynasty; collective body of the family; crime; court of law; Confucian morality; generational hierarchy; gender; social causes of crime

This work is licensed under a Creative Commons «Attribution» 4.0 International License 


\section{РУКА ЗАКОНА И ТЕЛО СЕМЕЙНОГО КОЛЛЕКТИВА. СЕМЬЯ, СТРАХ И СУД В ЦИНСКОМ КИТАЕ}

\section{Саракаева Ася Алиевна}

Хайнаньский университет. Хайкоу, КНР. Email: asia-lin[at]mail.ru

\section{Аннотация}

В статье через призму преступлений и судебньх дел рассматриваются сложные взаимоотношения между индивидом, семьей и государством в Китае XVII-XIX вв.. Объектом изучения послужили архивные судебные дела и художественная литература традиционного Китая. Автор исследует преступления, совершенные в рамках семьи, анализирует показания преступников и свидетелей, а также приговоры и правительственные указы; сравнивает реальные протоколы судебных слушаний с изображением семейных конфлииктов, следствия и суда в приключенческих романах и новеллах китайских писателей. В результате автор приходит к ряду выводов, в частности, о том, что цинское правительство постепенно смещало акцент с ценности сыновней почтительности и поколенческой иерархии в сторону особой значимости брачных отношений, в общественном же сознании, напротив, была чрезвычайно сильна инерция конфуцианства и стремление оградить целостность и автономию семейного организма от вмешательства государственной власти. Говоря же о реакции китайской семьи на произошедшее в ее рядах преступление, автор выделяет несколько типичных способов реагирования, где выбор способа зачастую определяется гендерной принадлежностью участников конфликта.

\section{Ключевые слова}

Китай; династия Цин; тело семейного коллектива; преступление; суд; конфуцианская мораль; поколенческая иерархия; гендер; социальные причины преступности 


\section{СЕМЬЯ, ПРЕСТУПЛЕНИЕ И НАКАЗАНИЕ В ТРАДИЦИОННОМ КИТАЕ. ВВЕДЕНИЕ}

Трудно переоценить значение семьи в эмоциональном и интеллектуальном мире традиционного Китая. Семья занимала особое место в конфуцианской идеологии: из так называемых «пяти человеческих отношений», регулировавших нравственные обязательства индивида перед обществом, три были отношениями родства - а именно, отношения отца и сына, старшего и младшего братьев, мужа и жены. Сыновняя почтительность называлась первейшей добродетелью человека, супружеская верность была краеугольным камнем женской добродетели. Гармония в семье считалась основой и истоком социального и политического порядка (Li \& Wang, 2014, pp. 195-205). На практическом уровне семья оказывала человеку психологическую, экономическую, если надо - то и физическую поддержку.

Но помимо экономической и социальной защиты, которую предоставляла каждому китайцу его семья, она же иногда выступала и ареной тайных или явных конфликтов. Иногда эти конфликты обострялись до такой степени, что в урегулирование их последствий вынуждено было вмешиваться государство. И такое вмешательство государства, судебные разбирательства, вопросы, задаваемые чиновниками, оправдания подсудимых, наложенные наказания и мотивировки приговоров позволяют с неожиданного ракурса посмотреть как на семью, так и на государство традиционного Китая, увидеть их подлинные, не декларативные проблемы и ценности, оценить их внутренний конффликтный потенциал.

В настоящей статье мы рассмотрим ряд преступлений, виновниками которых были близкие родственники жертв. Все эти дела относятся ко времени правления последней династии имперского Китая маньчжурской династии Цин, подавляющее большинство случаев приходится на период от 1662 до 1820 гг. Такой выбор исторического периода обусловлен источниковой базой, поскольку в архивах КНР не сохранились материалы более ранних судебных дел. Тем не менее, у нас есть возможность с определенной осторожностью экстраполировать полученные сведения и на более ранний период, опираясь на художественную литературу старого Китая, в которой весьма широко представлены темы преступления и наказания, освещены способы поиска преступника и доказательства его вины. Разумеется, в процессе художественного осмысления реальность семейного конфоликта и судебного процесса не могла не подвергаться некоторой трансформации, проходя 


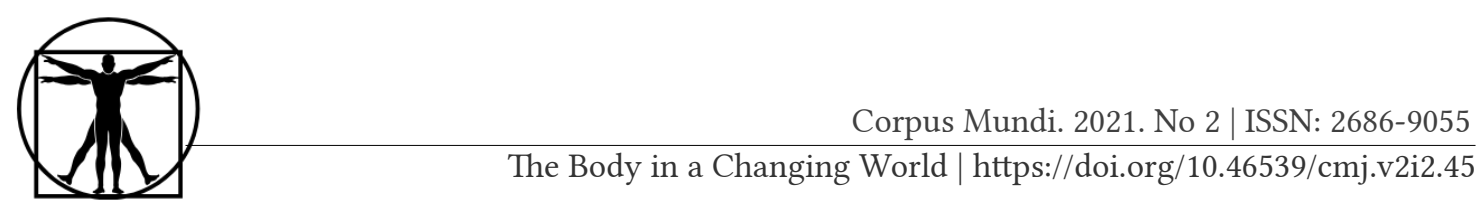

через призму авторского замысла и менталитета современного автору общества, но и подобные трансформации, сами по себе, могут служить интересным материалом для анализа. Как автор и его современники понимали семью, что, по их мнению, угрожало ее гармоничному существованию, кто был виновником конфликта? Какие типы преступлений попадали в фокус внимания новеллистов, а какие игнорировались? Как автор и его аудитория расценивали судебный процесс, что, в изложении писателей, мотивировало всех участников этого процесса? В рамках настоящей статьи мы постараемся ответить на эти вопросы, сравнивая подлинные судебные протоколы и их беллетризованное отражение в литературе.

Но прежде, чем приступить к этому анализу, следует кратко описать систему судопроизводства, с небольшими изменениями существовавшую в Китае на протяжение всего имперского периода, со II в. до н.э. до начала XX в. Понятие «закон» (律 lü или 法 fa) является одним из центральных для политической и административной мысли традиционного Китая, причем под законом всегда понимался именно и только уголовный закон; с древних времен предпринимались многочисленные попытки кодифицировать наложение наказаний, предусмотрев все возможные нарушения общественных и этических норм (Ames, 1994, p. 109).

Несмотря на это, на всем протяжении китайской истории судебные инстанции так никогда и не конституировались в отдельную ветвь государственного управления; проведение расследований, арест подозреваемых и судебное разбирательство были частью обязанностей муниципальных чиновников уровня начальников уездов или правителей областей. Задача этих чиновников осложнялась тем, что для занятия должности они должны были пройти через систему государственных экзаменов, которая, за исключением династии Хань (206 г. до н.э. - 220 г.), не требовала от соискателей знания законов, вместо того они должны были продемонстрировать глубокое владение классическими конфуцианскими трактатами и умение писать стихи или сочинения заданного образца. Чтобы помочь неопытным администраторам сориентироваться в пространных кодексах и следственных процедурах, в Цинское время (1644-1911 гг.), а возможно, и ранее, в судах появились секретари по юридическим вопросам - так называемые «знатоки наказаний» или «судебные друзья», экзаменов не сдававшие, зато начитанные в законах. Для производства обысков и арестов при ямынях (управлениях местных правителей) служили отряды стражи во главе с несколькими офицерами. 
В целом, процедура следствия и суда выглядела следующим образом: пострадавший - или любой человек, желающий сообщить о преступлении - приходил к ямыню и начинал стучать в специально установленный перед воротами барабан, на звуки барабана стража отворяла ворота, жалобщик, встретившись с чиновником, преклонял колени и излагал свое дело. Начальник уезда командировал стражников, чтобы доставить в суд подозреваемых и свидетелей, если же речь шла об убийстве, то труп сперва осматривал коронер - медик, состоящий на службе в ямыне, затем начальник должен был лично убедиться в соответствии медицинского заключения повреждениям на теле жертвы. Помимо прочего, труп изучали на предмет применения одного или двух наиболее распространенных ядов, чаще всего - мышьяка (Hegel, 2009, pp. 11-13). Затем чиновник проводил серию допросов, которые тщательно протоколировались. При необходимости применялась пытка, как правило - битье тяжелой или легкой бамбуковой палкой, изредка - сдавливание пальцев связкой бамбуковых дощечек. Если заседание суда было нужно прервать до обнаружения новой информации или поимки нового подозреваемого, то все причастные к делу, причем не только подсудимые, но и свидетели, могли быть заключены в тюрьму вплоть до следующего заседания, чтобы предотвратить побеги или неявки. Все слушания могли быть только открытыми, на них допускались все желающие, что призвано было предотвратить произвол со стороны чиновников.

После установления виновности и получения признательных показаний, без которых дело не могло быть закрыто, выносился приговор. В раннеимперский период наказанием за преступление мог быть каторжный труд, тот или иной вид членовредительства (татуирование лица, отрубание носа, стоп ног, кастрация) или смертная казнь через отрубление головы, разрубание туловища напополам или четвертование. Членовредительство было отменено как вид наказания довольно рано, примерно с 167 г., а с VI в. исчезает разрубание напополам и появляется удушение. Кроме того, иногда дозволялась замена казни или каторги штрафом. При династиях Цинь и Хань местный чиновник имел право не только приговаривать к смерти, но и приводить приговор в исполнение без согласования с вышестоящим начальством (Twitchett \& Fairbank, 2008, pp. 532-533). В точности неизвестно, когда этот порядок изменился, но, по крайней мере, во второй половине позднеимперского периода, в XVII-XIX вв, к которым относится наш основной материал, приговор должен был пройти массу согласований, включая столичную Палату наказаний и лично императора, перед тем, как он мог быть осуществлен. Самым распространенным наказанием 


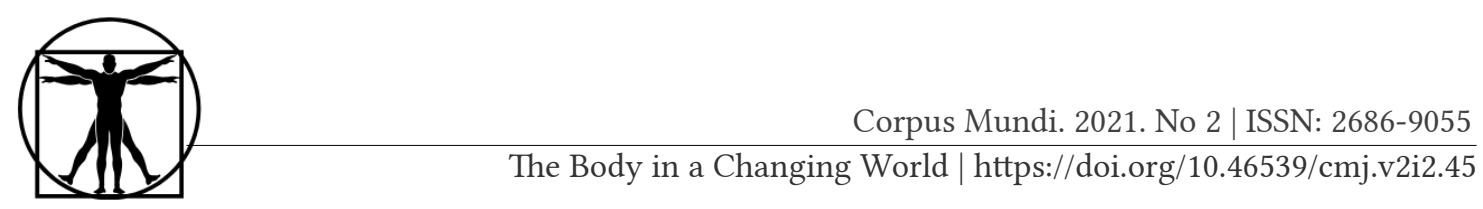

в это время становится порка тяжелой палкой, изгнание из родных краев, а случае тяжких преступлений - удушение или обезглавливание, которое могло быть совершено немедленно по получении императорского разрешения, или осенью, следующей после такого разрешения. И, наконец самым чудовищным преступлением считалось убийство нижестоящим членом статусной пары вышестоящего (убийство или покушение на убийство государя или члена императорской семьи, убийство отца сыном или дочерью, мужа - женой, свекров невесткой), за это предусматривалась мучительная и медленная казнь, при которой виновному срезали мясо с костей по кусочку.

Довольно сложным для цинских властей был вопрос о пределах юридических полномочий семейно-клановых коллективов. С одной стороны, правительство выступало за поддержание патриархальных отношений, за всемерное сохранение иерархий в обществе, а значит, и в семье. В Китае с древнейших времен само понятие «государство» формулировалось как 国家 (guojia), в буквальном переводе - «государство-семья». В таком государстве, организованном и воспринимаемом своими членами как огромная семья, полнотой власти обладал патриарх-император, делегировавший свои полномочия своим сыновьям-чиновникам, и они от его имени осуществляли заботливое управление детьми-народом, недаром в ранних текстах понятие «простой народ» выражалось с помощью метонимического оборота 子弟 (zidi) - «сыновья и младшие братья». Поэтому император и правительство не могли себе позволить подрывать авторитет патриархов, на котором, косвенным образом, держался и их собственный авторитет.

С другой стороны, столь же естественным было и недоверие бюрократического аппарата к клановому самоуправлению, находившемуся вне непосредственного контроля государства, и не желающему руководствоваться писанными законами. Так, в 1726 г. император Юнчжэн предпринял попытку инкорпорировать поколенческие структуры семейного управления в административный аппарат на правах его низового звена: государство объявило о формальном признании статуса «главы клана» 族长 (zuzhang), и возложило на него обязанности профилактировать преступления в клане. А в 1727 г. отдельным указом император конкретизировал дозволенные семейным организациям методы воздействия на рецидивистов: «...в отношении порочных преступников, которые уже понесли наказание от чиновников, но так и не раскаялись, и оттого стали ненавистны всему клану, членам клана позволяется, уведомив о том чиновников, изгонять их (преступников А.C.) в дальние области, чтобы избежать опасности, угрожающей всей семье. Или же, если преступник получает наказание в соответствии 
с семейными правилами, и это приводит к его смерти, то (главы клана, ответственные за это - А.С.) будут избавлены от казни» (Theiss, 2004, p. 68-69). Но уже следующий император, Цяньлун, отнял у глав кланов право наказывать, допрашивать и изгонять своих провинившихся родственников, оставив за ними лишь полномочия задерживать преступников до распоряжения местного начальства. Ряд уточняющих указов установил меру ответственности глав семейств за неудачную попытку медиации, отныне, если старейшины клана пытались своими силами разрешить противоречия между родственниками вместо того, чтобы немедленно обратиться в ямынь, и это приводило, в конечном итоге, к насилию или самоубийству какой-либо из сторон конфбликта, то старейшины должны были получить наказание вплоть до 80 ударов тяжелой палкой (Theiss, 2004, pp. 69-71).

Таким образом, контекст тех судебных дел, о которых мы собираемся говорить, был глубоко противоречив, он, с одной стороны, основывался на необычайно долгой преемственности самой модели государственного управления, на стабильном правосознании китайского народа, на почти полном консенсусе по вопросам закона и морали, с другой стороны, в нем подспудно присутствовал неустранимый конфликт бюрократии и родового самоуправления. В Китае есть пословица, эквивалентная латинскому “Dura lex, sed lex” («Закон суров, но это закон»), в буквальном переводе она гласит: «У государства есть законы, у семьи есть правила». Но что же делать, если государственные законы входят в противоречие с семейными правилами?

\section{БЫТОВЫЕ ПРЕСТУПЛЕНИЯ}

Разумеется, значительная часть дошедших до нас дел - бытовые преступления: непреднамеренные убийства в результате стихийно вспыхнувшей ссоры, но и они могут предоставить немало интересных сведений. Так, в 1728 г. в Хунани в двух соседних деревнях проживали два брата, Хун Куньвэй и Хун Яочжан, младший из них, Яочжан, собрал кучу навоза для удобрения своих полей и обещал оставить несколько ведер для брата. Однако, когда пришло время вносить удобрения, оказалось, что этой кучи едва достаточно на его собственное поле, так что для брата ничего не осталось. Вскоре после этого братья случайно встретились на дорожке между полями, и Куньвэй начал ругать брата за невыполненное обещание, и понемногу так разозлился, что скинул груз, который он нес на коромысле, и принялся этим коромыслом бить Яочжана. Тот не хотел вступать в драку и кинулся убегать, но, к несчастью, добежал до канавки, через которую не смог перепрыг- 


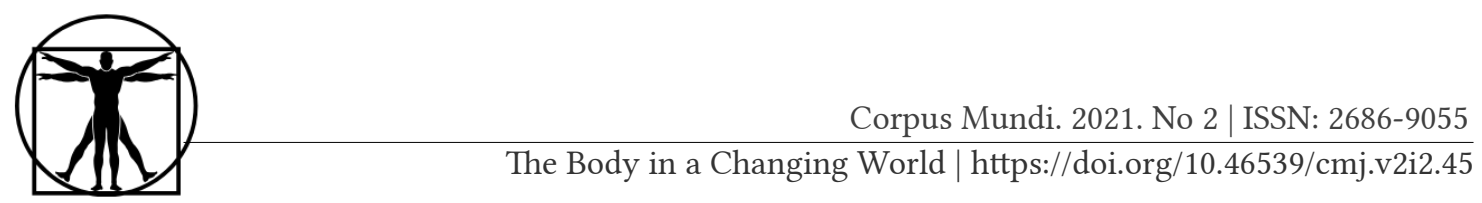

нуть, и вынужден был повернуться и защищаться. Он отобрал у старшего брата коромысло и нанес этим коромыслом всего один удар по правому виску, и Куньвэй упал. Тем временем, к ним уже бежали их племянники Хун Шицзе и Хун Вэньтао, чтобы разнять дерущихся. Они подняли пострадавшего с земли и отвели в свой дом, но через четыре дня он умер (Hegel, 2009, pp. 128-133).

При всей простоте дела, несмотря на наличие двух свидетелей, судебный инспектор провел следствие со всей возможной тщательностью, допросив даже сына покойного, который точно не был на месте преступления, и внес в протокол его показания: «Я еще слишком молод и не знаю, как нужно говорить. Моя мама уже дала показания о том, как отец был забит до смерти» (Hegel, 2009, p. 130). Инспектор несколько раз переспрашивал у разных членов судящейся семьи о том, кому принадлежала навозная куча - лично Хун Яочжану или все-таки обоим братьям совместно, вероятно, с его точки зрения, факт расходования всего навоза из совместной кучи усугублял бы вину убийцы. Яочжан не отрицал своей вины, признавал, что он достоин смерти, и был приговорен к татуировке и отрублению головы за убийство старшего родственника. Но непосредственно на месте судебный инспектор не смог решить вопроса о необходимости наказать племянников жертвы и убийцы, Шицзе и Вэньтао; их не подозревали в соучастии, но вменяли им в вину то, что они не предотвратили разыгравшуюся на их глазах трагедию. Приговор убийце был утвержден в столичной Палате наказаний, и только там было принято решение об освобождении племянников от ответственности (Hegel, 2009, p. 133).

При почти аналогичных обстоятельствах преступления, приговор был существенно иным в деле об убийстве Ли Второго его младшим братом в Фэнтяне в 1738г. Согласно показаниям самого виновника и жены убитого, братья Ли незадолго до происшествия разделили свое имущество и стали вести отдельные хозяйства, но еще не поделили две меры (примерно 20 литров) бобов, которые пока хранились в доме младшего. Однажды Ли Третий пришел к брату в гости и стал вместе с ним выпивать, разговор дошел и до бобов, и старший брат упомянул, что хочет забрать свою долю. Ли Третий объяснил, что их общая мать, проживавшая с ним, продала эти бобы и на вырученные деньги купила ткань. Объяснение, тем не менее, не удовлетворило Ли Второго, и началась драка. Жена убитого в это время вышла из дома, поэтому детали драки известны только по показаниям убийцы. От утверждал, что брат повалил его на кан и стал бить, он решил припугнуть брата и заставить его отступить, и потому дотянулся до маленького ножа, который 
Ли Второй носил на поясе, и случайно ткнул его в бедро. На следующий день старший брат умер, а младший был арестован.

Он был подвергнут пытке, но и под пыткой продолжал утверждать, что не имел намерения убивать. Судья поверил его показаниям, и потому классифицировал произошедшее не как убийство младшим старшего, но как ранение, причиненное младшим братом старшему и повлекшее его смерть, но и этот состав преступления должен был привести Ли Третьего к немедленному отрублению головы. Но в то самое время, когда чиновник Палаты наказаний уже писал рапорт с рекомендацией обезглавить Ли Третьего, в ямынь с прошением явилась мать братьев Ли. Она заявила, что она вдова, ей 72 года, и других детей, кроме Второго и Третьего, у нее нет, теперь старший сын погиб, если же казнят и младшего, то «...мне не у кого будет искать поддержки, и некому будет меня похоронить. Это будет очень прискорбно. Ни одной капли нашей крови мои сыновья не передали (потомкам - А.С.). Если оба мои сына умрут, то жертвоприношение предкам моего мужа с этого времени полностью прервется» (Hegel, 2009, p. 125).

Это прошение сразу поменяло перспективу. Палата наказаний, впрочем, поручила чиновнику в Фэнтяне выяснить, насколько правдивы факты, изложенные в прошении. Ответ гласил, что матери братьев Ли, урожденной Ван, всего 61 год, у нее, в самом деле, нет других сыновей, зато у Второго Ли есть три сына, старшему из которых уже 15, и у Третьего Ли есть трехлетний сын. Тем не менее, автор доклада на высочайшее имя рекомендовал смягчение наказания до трех месяцев ношения канги и 40 ударов тяжелой палкой, с тем чтобы убийца мог продолжить заботиться о своей матери и приносить жертвы отцу и его предкам. Чем закончилось это дело, и удалось ли Ли Третьему сохранить жизнь, неизвестно, поскольку император Цяньлун не принял окончательного решения, передав, вместо того, дело на пересмотр Трем палатам (своего рода высшей апелляционной инстанции империи Цин) (Hegel, 2009, p. 127).

В этом деле замечательно, как нормы конфуцианской морали вступают между собой в конфоликт. С одной стороны, посягательство младшего на старшего понималось как угроза всему общественному порядку, с другой - требование сыновней почтительности было столь императивным, столь довлеющим даже над законом и центральным правительством, что оно перевесило тот факт, что подательница прошения, госпожа Ван, как минимум дважды солгала - завышая свой возраст и отрицая наличие внуков, которые вполне могли бы сами приносить жертвы своему деду. 


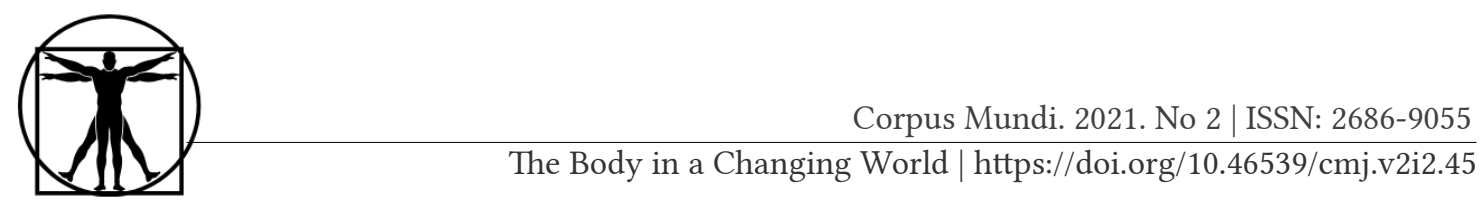

В мае 1794 года в провинции Чжили (нынешний Хэбэй) мелкому помещику по имени Го Тинъи сказали, что его племянница, вышедшая замуж менее двух месяцев назад, неожиданно повесилась в доме мужа. Дядя взял с собой местного старосту и поспешил в дом семьи Цзо, где и увидел тело своей племянницы, недавно вынутое из петли. Однако он сразу разглядел, что на ее груди и шее есть раны, и потому не поверил в ее самоубийство. Го Тинъи и свекр покойницы, Цзо Юаньжан, насели с вопросами на мужа молодой госпожи Го, Цзо Цинсюаня, и тот признался, что случайно зарезал свою жену, запаниковал и решил замаскировать ее смерть под самоубийство.

Будучи арестованным, он подробно рассказал на допросе, что у них с женой были «гармоничные отношения», они хорошо ладили вплоть до последней ночи, когда, ложась спать, госпожа Го сказала ему, что хотела бы на следующий день отправиться погостить у своего дяди. Он не согласился, мотивируя это тем, что они оба всего несколько дней назад вернулись домой от Го Тинъи, и незачем идти туда вновь. Жена заупрямилась, они поссорились, и ночью она отказала ему в супружеской близости. Наутро он был зол, сидел на кане, прочищая ножом засорившуюся курительную трубку, и искал повода придраться к жене, и поэтому стал выговаривать ей за одежду, разбросанную по кану, и даже ударил ее трубкой по спине. Затем, как он утверждает, неожиданно для него, она развернулась и стала бить его в ответ, он не успел убрать руку с ножом, и нож попал ей в сердце.

Начальник уезда, судя по протоколу, не выразил недоверия к такой несчастной случайности, зато буквально каждого, опрошенного по делу, - а в бумагах сохранились показания пятерых человек - он спрашивал, каковы были отношения между молодыми супругами, и все в один голос отвечали, что отношения были вполне «гармоничными». Цзо Цинсюаня приговорили к удушению осенью (Hegel, 2009, pp. 52-58).

Во всех трех упомянутых делах обращает на себя внимание особый интерес судей к характеру взаимных отношений между убитым и убийцей. Кому принадлежала навозная куча, то есть не было ли у младшего брата какого-либо дополнительного, корыстного, мотива для убийства старшего? Хорошо ли ладили между собой недавно разъехавшиеся братья Ли? Не было ли между новобрачными ненависти, которая могла бы подтолкнуть мужа к предумышленному убийству? И с тем же упорством, в одном случае, даже и под пыткой, подсудимые повторяют, что у них не было ни малейших ссор с пострадавшими, что жертвы сами начали их бить, и вообще, по сути дела, сами напоролись на нож или попали под коромысло. Таким образом, очевидно, что для цинского суда все более важен становится вопрос о наличии умысла 
на совершение преступления, тогда как в предшествующей истории Китая, в соответствии с конфуцианскими нормами человеческих отношений, определяющим степень вины принципом был социальный или семейный статус - убийство младшим родственником старшего было чудовищным преступлением, вне зависимости от намерений убийцы, а вот старший родственник мог отделаться довольно легким наказанием за убийство младшего, даже если действовал осознанно.

Для иллюстрации этого тезиса можно обратиться к художественной литературе. Так, в повести минского новеллиста Лин Мэнчу (1580-1644) «Утаенный договор» рассказывается о юноше Лю Анчжу, который прибыл из далеких краев в столицу, на родину своего покойного отца, где все еще жил его дядя. В руках у него был договор, подписанный отцом и дядей много лет назад, согласно которому семейное имущество должно было делиться между братьями, а в случае смерти одного из братьев на чужбине, его доля должна была отойти его сыну. К несчастью, дяди, Лю Тяньсяна, не было дома, и поэтому юношу встретила его жена. Ссылаясь на невозможность пустить в дом постороннего мужчину, она оставила Анчжу за порогом, только выманила у него договор, чтобы предварительно изучить его и понять, не подделка ли это. Когда же хозяин вернулся домой, злобная женщина, которая надеялась передать все богатство семьи Лю собственной дочери и зятю, наотрез отказалась признавать племянника, заявила, что никакого договора она не видела и не брала, и даже ударила Анчжу по голове так сильно, что он потерял сознание. Несчастный провинциал вынужден был обратиться за помощью в столичную управу, которую в это время как раз возглавлял прославленный своей проницательностью и неподкупностью судья Бао по прозвищу Драконова Печать.

Бао предложил юноше в отместку за понесенную обиду самому побить Лю Тяньсяна или его жену, на что тот ответил категорическим отказом: как у него поднимется рука на старшего родственника? Так судья Бао удостоверился в правдивости истца. После чего судья распорядился спрятать Анчжу, а супругам, вызванным в суд, объявить, что юноша скончался вследствие полученного удара по голове. И, когда женщина продолжала отрицать их родство, Бао с сожалением сказал: «Если бы вы были родственники, все было бы проще. Ты старшая, он младший. Даже если бы ты прибила его насмерть, можно сказать, что это случилось нечаянно. Смерть младшего от старшего из родни не считается убийством, и мы бы ограничились простым штрафом. А вот ежели вы не родня, дело усложняется. На этот счет есть такое правило: «Взял в долг - верни, убил человека - заплати жизнью!» (Проделки, 1989, с. 59). И он приговорил ее к казни. В ужасе, тетка сразу 


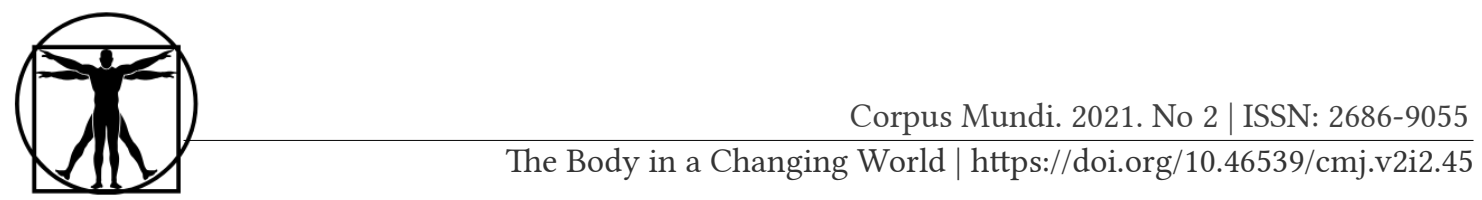

заявила, что юноша ее племянник, и продемонстрировала спрятанный ею документ. Так судья Бао доказал вину тетки и личность племянника (Проделки, 1989, сс. 41-60).

Итак, по свидетельству писателя, в его время, или во времена династии Сун, о которых идет речь в данной новелле, существовал порядок, согласно которому убийство старшим родственником младшего не рассматривалось как серьезное преступление. Однако реальная судебная практика XVIII столетия уже демонстрирует совершенно иные тенденции.

\section{УБИЙСТВА ПО КОРЫСТНЫМ МОТИВАМ}

Еще более информативными для нас являются случаи, в которых преступный умысел присутствовал, ибо они позволяют чуть глубже заглянуть в modus vivendi традиционной китайской семьи, во внутренний мир преступников и мышление судей.

В 1729 году, сразу же после Нового года, в уезде Синъян провинции Хунань у Ли Хуаймина умерла жена, урожденная Лю. Ее брат, Лю Синлун, был в очень хороших отношениях с сестрой и зятем и даже какое-то время жил в их доме, и потому, узнав о смерти сестры, сразу пришел к зятю, чтобы сжечь поминальную бумагу в жертву покойнице. Подходя к дому, он увидел старшего брата своего зятя, Ли Хуайюя, и спросил, куда тот направляется. Оказалось, что Хуайюй намеревался купить водяного буйвола, следовательно, как немедленно заключил Лю Синлун, у него были с собой деньги, и их можно было у него какимто образом выманить. Позже, на допросе, он объяснит свое поведение: «Я всегда был чрезвычайно беден» (Hegel, 2009, p. 48). Поэтому он обманул собеседника, сказав, что у него есть подходящий буйвол, и на следующий день они могут вместе пойти в деревню, где жил Лю Синлун, и посмотреть буйвола. Покупатель согласился, но продавец был вовсе не уверен, что сделка состоится, и поэтому решил привлечь к делу их общего с Ли Хуайюем родственника - Чжоу Саньмина, который был племянником его собственной жены, и мужем племянницы Ли. Лю Синлун уговорил Чжоу Саньмина проследить, чтобы покупатель не пошел за буйволом ни в какое другое место, а непременно наутро повел его в деревню. Сам же он заночевал в доме своего зятя, принес жертвы духу сестры, а уходя, незаметно прихватил из дома топорик.

На следующий день они втроем, Лю Синлун, Ли Хуайюй, и еще не знающий, во что он ввязался, Чжоу Саньмин, вместе отправились в деревню. Когда стемнело, они дошли до запруды семьи Гэн, перепра- 
вились через нее, и в этот момент Лю Синлун достал из-за пазухи топорик и нанес Ли Хуайюю два удара по голове, от чего тот погиб на месте. Чжоу Саньмин, шедший позади них, пришел в ужас и сразу убежал, а убийца обыскал труп, но нашел на нем только скромную сумму в тысячу триста медных монет. Восемьсот он оставил себе, еще пятьсот отдал впоследствии Чжоу Саньмину.

Труп остался лежать непогребенным возле запруды, где его вскорости и нашли хозяева земли - крестьяне по фамилии Гэн и староста той местности. Однако они единогласно решили никому не рассказывать о своей находке, и просто зарыть тело. На последовавших допросах они оправдывались тем, что труп был одет в изношенные лохмотья, и поэтому они приняли его за замерзшего нищего, и это несмотря на то, что все они признали, что заметили на его лице черные раны (Hegel, 2009, p. 41).

Тем временем, брат убитого, Ли Хуаймин, похоронив жену, отправился в горы рубить дрова, а по возвращении оттуда узнал, что его старший брат пропал. Жена брата, урожденная Сюн, рассказала, что Ли Хуайюй незадолго до своего исчезновения продал поле и выручил за него 16 лян серебром - довольно значительные деньги, правда, как она признает на допросе, сама она их не видела и знает о них только со слов мужа. Впоследствии в ходе допросов выяснилось, что поле было давно уже заложено за 12 лянов, Ли Хуайюй потерял надежду когда-нибудь собрать такую сумму и выкупить его, и потому согласился продать его своему кредитору, так что на руки в этот раз он получил всего 4 ляна. Это объясняет, почему с ним была найдена лишь небольшая сумма денег. Любопытно, впрочем, что его жена ничего этого не знала. Зато она точно знала, куда и с кем ушел ее муж. Почемуто в протоколах суда отсутствует упоминание о том, расспрашивал ли Хуаймин спутников своего брата о его судьбе и местонахождении, но известно, что после недолгих поисков он решил, что его брат, имевший склонность к спиртному, просто напился и утонул в какойнибудь из рек или канав по пути. Он не стал заявлять властям об исчезновении брата, но продолжал время от времени спрашивать людей, не видели ли его где-нибудь.

Так продолжалось до мая 1734 г., когда к Ли Хуаймину подошел Чжоу Саньмин и сказал: «Есть семейное дело, которым тебе следовало бы заняться», и затем рассказал ему о судьбе его брата. Чжоу Саньмин посоветовал брату убитого поговорить об этом с убийцей и потребовать от него денег, а потом часть этих денег отдать ему самому, Чжоу Саньмину. Ли Хуаймин, тем не менее, не посмел заводить такие разговоры с предполагаемым преступником, вместо того, он пошел поговорить 


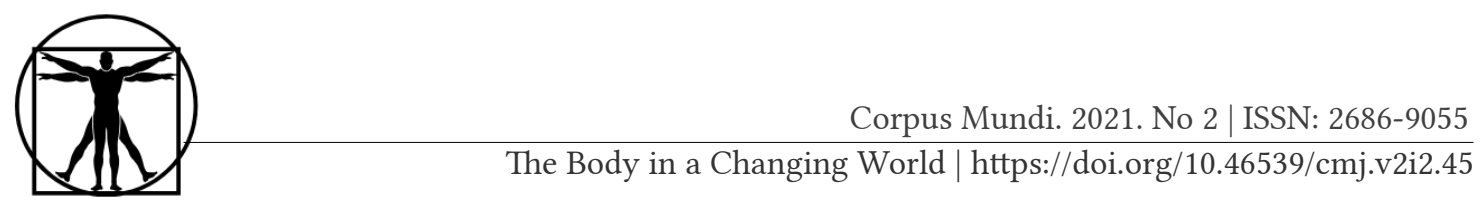

с его младшим братом, Лю Юнчжэном, и тот подтвердил, что Синлун сознался ему в этом убийстве и выразил свое раскаяние. На суде чиновник не поверил, что младший брат безо всякого давления согласился свидетельствовать против старшего, но Лю Юнчжэн объяснил, что его еще пятилетним ребенком продали в услужение в богатый дом, он отработал свой контракт и освободился всего год назад, и не был когда бы то ни было близок со своим братом. Итак, получив признание двух человек, Лю Хуаймин, наконец, решился пойти в ямынь.

Пытать никого не пришлось: подозреваемые и свидетели рассказали все без утайки, труп был эксгумирован, раны соответствовали описаниям. В ходе следствия Чжоу Саньмин скончался в тюрьме, а Лю Синлун был приговорен к немедленному отрублению головы. Но на этом наказания не закончились: в своем докладе Палате наказаний хунаньский чиновник рекомендовал приговорить крестьян из семьи Гэн, обнаруживших и похоронивших тело на своей земле, к 80 ударам палкой, со смягчением приговора до 30 ударов; брату убийцы, Лю Юнчжэну, должны были назначить 100, а на самом деле дать 40 ударов за недонесение; и, самое, на наш взгляд, парадоксальное наказание - брат убитого, Ли Хуаймин, доложивший о преступлении и не совершивший ничего противозаконного, должен был получить номинально 80, а по факту 30 ударов за то, что орудие преступления было украдено именно из его дома (Hegel, 2009, pp. 37-52).

Через все это запутанное следственное дело красной нитью проходят два основных лейтмотива: отчаянная нищета и нежелание иметь дело с государственными властями. Лю Хуайюй так беден, что вынужден закладывать основное средство производства - свою землю, причем даже без надежды выкупить ее назад, и отправляясь совершать важную покупку, он все равно одет так, что его посмертно принимают за нищего. И, тем не менее, для своих убийц даже он богач, которого стоит ограбить. Неудивительно, что в таких условиях человеческая жизнь, семейные и дружеские связи оказываются дешевле связки медных монет.

Другой чертой, характеризующей поведение всех участников этой драмы, является избегание любых контактов с ямынем. Обнаружив подле своей запруды труп, семья Гэн и их соседи решают не связываться с властями и просто закопать его. Став невольным соучастником убийства, Чжоу Саньмин предпочитает рассказывать об этом своим собутыльникам и даже пытается руками своего дяди шантажировать убийцу, но не доложить о происшествии в управу. И даже Ли Хуаймин, который беспокоится за своего брата и ищет его, не заявляет об его 
исчезновении тотчас же, хотя прекрасно знает, с кем и куда ушел брат в тот роковой день. Впрочем, учитывая наказания, наложенные судьей и впоследствии утвержденные императором, нельзя сказать, что страхи всех причастных к делу были беспочвенны.

Тот же жгучий коктейль нищеты, отчуждения и отсутствия сколько-нибудь внятного планирования демонстрируют и другие судебные дела из этой категории.

Интересно, что все эти психологические признаки, управляющие поведением как преступников, так и пострадавших, полностью игнорируются художественной литературой. Так, в новелле Лин Мэнчу «Поле алых цветов» вполне зажиточный пасынок сразу же после смерти отца выгоняет из дома его наложницу и ее сына, своего собственного маленького брата, и даже дает суду взятки, чтобы только не делиться с ними отцовским наследством; а дядя, человек столь богатый и с такими связями, что его боятся даже местные чиновники, посылает нанятых головорезов ограбить своего юного племянника (Проделки, 1989, сс. 652-687). Знаменитый приключенческий роман Ши Юй-куня «Трое храбрых, пятеро справедливых» (1850-1870е гг.) повествует о свершениях великого судьи Бао Чжэна и его помощников - отважных рыцарей, защитников несправедливо обиженных, это произведение особенно важно для нас, так как изобилует описаниями преступлений и расследований. Однако изо всех многочисленных преступлений, упомянутых в этом романе, только два совершены по чисто корыстным мотивам: мясник убивает случайно зашедшую к нему в дом девушку, чтобы завладеть ее драгоценными шпильками; богатый помещик убивает своего кузена, чтобы не возвращать ему долг и присвоить принадлежащее ему волшебное изголовье (Ши, 1974, сс. 75-84). В обоих упомянутых литературных произведениях корыстные преступления совершаются не голодающими низами общества, а вполне обеспеченными людьми - помещиком, торговцем, высокопоставленным чиновником в отставке, и единственной причиной этих убийств объявляется, таким образом, нравственное несовершенство преступников, их жадность и жестокость, тогда как социальные причины преступности авторам незнакомы.

\section{УБИЙСТВА ОБМАНУТЫХ СУПРУГОВ ИЗМЕННИЦАМИ И ИХ ЛЮБОВНИКАМИ}

Преступления на почве страсти и ревности, напротив, привлекали к себе преимущественное внимание минских и цинских писателей их труды буквально изобилуют описаниями подобных злодеяний. 


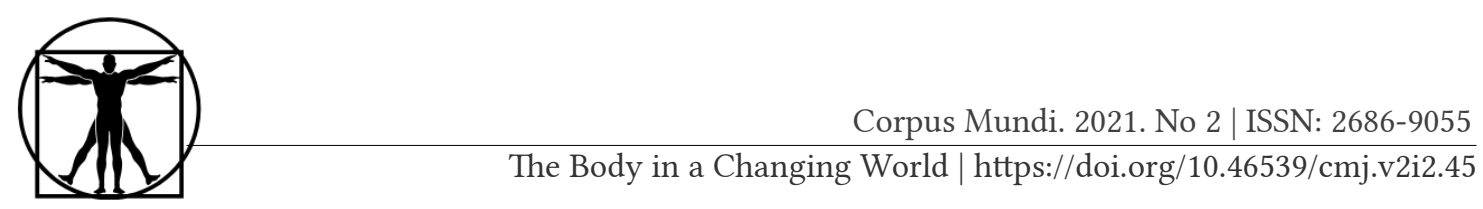

Однако о причинах такого интереса мы расскажем немного позже, а сначала рассмотрим несколько реальных дел из этой категории.

В 1803 г. в деревне Мацуньбао в Шаньси некий Ли Цан торговал персиками, сложив их кучей прямо перед воротами своего дома. Он не хотел выпускать товар из виду, и потому даже обедал на улице, не заходя домой. Он ел паровые пельмени и болтал со своими кузенами по фамилии Ли и Дуан, которые как раз проходили мимо его дома. И вдруг он сказал, что у пельменей какой-то неприятный вкус, и кинул остаток еды из своей плошки собаке кузена. Потом ему стало нехорошо, и он вернулся домой и лег, а его двоюродные братья пошли по своим делам. Однако вскоре собака умерла в корчах, и ее хозяин решил, что надо бы предупредить об этом Ли Цана. Вернувшись в дом Ли Цана, кузены обнаружили его в агонии, а ночью он умер.

Местный староста доложил о его подозрительной смерти в ямынь, тело было осмотрено, медицинское заключение гласило, что смерть наступила вследствие отравления мышьяком. Когда же чиновник опросил свидетелей происшествия, то один из кузенов рассказал, что врач из их деревни по имени Дуан Шичжо часто навещал дом покойного, причем во время его визитов Ли Цан уходил из дома, оставляя гостя наедине со своей женой, и потому соседи шептались, что жена Ли, урожденная Цзя, сошлась с врачом, а Ли Цан им сводничает. Будучи допрошенной, госпожа Цзя сразу же и без принуждения призналась, что она, и вправду, вступила в незаконную связь с Дуан Шичжо, а потом по его наущению отравила мужа.

Сам врач тоже не стал запираться и пояснил ситуацию: он вступил в отношения с госпожой Цзя и стал навещать ее и приносить ей то рис, то ткань, то небольшие суммы денег. Ли Цан узнал об этом, но дал жене понять, что он не против, а примерно через восемь или девять месяцев он потребовал от Дуана четыре ляна серебра якобы в долг. Дуан Шичжо отказал ему, так как сумма была немаленькая, а дела его шли не слишком хорошо. В следующем месяце Ли Цан вновь попросил «в долг», хотя и более скромную сумму в три тысячи медных монет, но и в этот раз получил отказ. Тогда он рассердился и потребовал от жены прекратить адюльтер, а иначе он убьет обоих любовников. Но Дуан Шичжо был слишком влюблен (в протоколах это называют «горячие чувства» или более нейтрально «близкие чувства»), чтобы расстаться со своей любовницей, поэтому он принялся уговаривать ее отравить мужа и выйти замуж за него, и тогда уже они смогут всегда быть вместе. Она боялась разоблачения, но Дуан уверил ее, что, если только Ли Цан умрет вне собственного дома, то ее никто и не заподо- 
зрит. Он принес мышьяк, и она добавила его в мясную начинку для пельменей.

Поскольку Ли Цан знал о прелюбодеянии жены и покровительствовал ему, то госпожа Цзя была избавлена от казни путем медленного срезания плоти с костей, ее приговорили к немедленному обезглавливанию. Дуан Шичжо должен был подвергнуться татуированию лица словами «порочный преступник», а также отрублению головы осенью. Палата наказаний, Три управы и император утвердили приговор (Hegel, 2009, pp. 58-64).

Современный читатель мог бы удивиться тому, что смягчающим вину фактором было сочтено покровительство адюльтеру со стороны обманутого мужа, а вот факт его угрозы убийством совсем не был принят во внимание. Однако в данном случае Ли Цан действовал в пределах своих супружеских прав: по закону муж мог безнаказанно убить жену и любовника, если заставал их на месте преступления. Сходные законы существовали в Китае уже давно: еще при династии Тан (618-907 гг.) убийство прелюбодея интерпретировалось как аналогичное убийству грабителя, который ворвался в дом ночью, и, как и в случае с грабителем, право на убийство изменницы и ее любовника распространялось на всех членов семьи мужа и даже на слуг. Последующие династии то сужали, то расширяли это право, а в XVIII веке правительство Цин предприняло несколько попыток определить, кто мог убить, кого, и при каких обстоятельствах. Впрочем, как и в случае с юридическими полномочиями глав кланов, в этом вопросе мнение цинских властей колебалось. Так, в правление императора Юнчжэна, в 1725 г., статья минского кодекса об освобождении мужа от ответственности за убийство прелюбодеев была развернута в отдельный закон, по которому право на такое убийство давалось всей родне как мужа, так и жены, за исключением младших родственников. Затем, уже во второй половине века, этот закон разросся до целой секции в попытках предусмотреть все возможные сценарии, такие как случайное или умышленное убийство посторонних или родственников во время обнаружения прелюбодеев, а также специальные статьи о поимке любовника в спальне наложницы, девушки, отданной замуж еще в детстве и выращенной в доме свекров, но еще не успевшей консумировать брак, незамужней дочери, просватанной дочери или юного сына. Из этого очевидно, что эта тема оставалась общественно значимой с точки зрения законодателя. Но тем не менее, уже в 1740 г. право на убийство прелюбодеев вновь ограничилось только обманутым мужем, тогда как остальной родне такой самосуд грозил трехлетней ссылкой и 100 ударами тяжелой палкой. Зато смягчалось наказание 


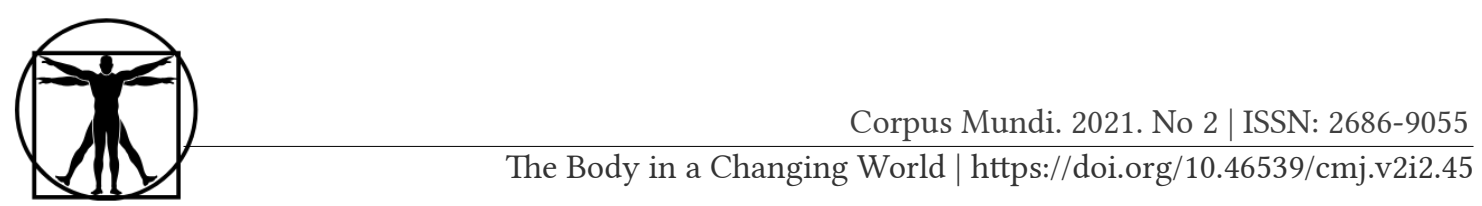

для мужа, который убивал любовника жены, или же ее саму не непосредственно во время поимки in corpo delicti, a несколько позже. В 1756 г. был издан закон, освобождавший мужчину от казни за убийство своего старшего родственника, если он заставал отца или дядю за развратом со своей женой и при этом не успевал понять, кто это такой. Если же он знал, что этот человек - его отец или дядя, то мог его только безнаказанно ранить, но не убивать (Theiss, 2004, pp. 100-108).

При всей кажущейся противоречивости этих законодательных новаций, они все же объединены общим, характерным для цинского законотворчества постепенным ослаблением патриархальных норм. Мы полагаем, что даже закон 1725 г., давший право убивать изменницу и ее любовника всем родственникам, тоже ослабляет, а не укрепляет патриархальный клан, ведь это право распространяется не только на род мужа, но и на посторонних ему людей - родню жены. Таким образом, ценность личной и семейной чести ставится выше, чем сплоченность и автономия клана мужа, размывается представление о том, что замужняя женщина отныне принадлежит исключительно семье мужа и попадает под полную власть патриарха этой семьи. Закон 1740 г. идет еще дальше в этом направлении, он вообще лишает патриархов права карать женщину, и хотя она по-прежнему остается в глубокой зависимости, но зависит она отныне только от мужа, а не от старших мужчин в его роду. А нарушение этого эксклюзивного права на женщину со стороны старшего родственника с 1756 года начинает быть столь вопиющим злоупотреблением властью, что если и не отменяет, то серьезно ограничивает поколенческую разницу в полномочиях членов семьи. Проще говоря, цинский законодатель очень постепенно, но неуклонно проводит мысль о приоритете нуклеарной семьи над кланом и о привилегированном статусе супружеских отношений в структуре всех родственных связей в целом.

С нашим выводом согласен ряд исследователей-китаистов. Так, Дженет Тейсс комментирует цинские законы о вторичном браке вдов:

\footnotetext{
«...мы видим небольшой сдвиг в том, как юридическая система определяет отношения между патриархатом и целомудрием, и это сдвиг акцента от отцов и глав семей к мужу как тому самому человеку, которому женщина обязана повиновением и верностью» (Theiss, 2004, pp. 99-100).
}

Норман Кутчер, изучавший практику предоставления чиновникам отпусков для совершения траура по родителям, приходит к очень близкому заключению, что цинская династия постепенно «освобождалась» от конфуцианских траурных церемоний и, таким образом, вытесняла сыновнюю почтительность с ранее принадлежавшего ей места норма- 
тивного центра всей системы семейных и политических ценностей (Kutcher, 1999).

Разрешение мужьям убивать любовников, застигнутых на месте преступления, не могло, разумеется, не порождать злоупотреблений. Так, в июле 1696 г. в уезде Ляочэн провинции Шаньдун властям доложили о том, что некий Ду Хуайлян застал свою жену, урожденную Чжан, с чужим мужчиной, и зарубил их обоих топором. Будучи допрошен, он заявил, что лег спать во дворе, чтобы постеречь свой скот, и проснулся среди ночи от того, что входная дверь его дома приоткрылась и затворилась. Тогда, взяв топор, он подошел к двери, прислушался и услышал шепот двух человек. Он ворвался в комнату, где увидел свою жену на кане и полураздетого мужчину, в котором он узнал своего бывшего квартиранта Чэнь Вэньсяня, и тотчас зарубил их обоих, о чем и сообщил своим родителям и соседям, а наутро - властям. Он утверждал, что в течение нескольких месяцев, когда Чэнь с женой снимали комнату в его доме, он замечал, как жилец и госпожа Чжан обмениваются взглядами, но ничего не говорил и не делал, так как не имел доказательств.

Соседи его, однако же, выразили сомнение в этой версии произошедшего, поскольку, согласно их описанию, госпожа Чжан, хоть и хромая, была хорошей и достойной женщиной, а Чэнь Вэньсянь работал так много, что не всегда имел время и силы дойти до дома.

Тем временем, в управу с жалобой пришла урожденная Ли, вдова Чэнь Вэньсяня, она утверждала, что Ду нарочно заманил ее мужа к себе домой, - это он пригласил Чэня выпить вина по старой дружбе.

Когда чиновник пригрозил Ду Хуайляну пыткой, тот изменил показания и сознался в предумышленном убийстве. Он рассказал, что вступил в связь с госпожой Ли, но даже не догадывался, что об этом узнала его собственная мать. И вот однажды, когда он ударил свою жену за неприготовленный вовремя обед, за нее неожиданно заступилась свекровь и стала бранить сына, что он бьет жену по наущению «этой шлюхи» Ли. Ли услышала эти слова, вышла и вступила в перепалку со старухой. В результате она уже не могла больше жить в доме Ду, и на следующее утро они с мужем уехали жить в другой дом. Все отношения между любовниками оказались прерваны. Но вот Ду никак не мог забыть о своей любовнице и все время сравнивал ее со своей невзрачной и хромой супругой. Тогда ему и пришла идея отделаться от обоих мешающих ему людей разом: он зазвал Чэня в гости и зарубил его, а затем и госпожу Чжан. Урожденная Ли вынуждена была признать правоту его показаний, с той только поправкой, что, по ее словам, их внебрачная связь началась с изнасилования. Кроме того, она 


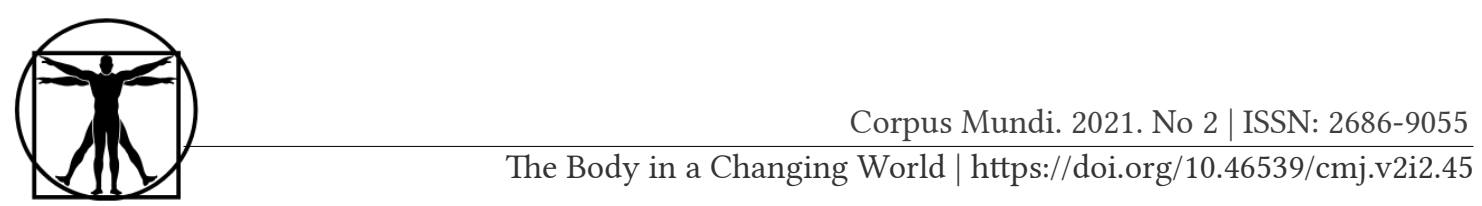

настаивала, что не хотела больше изменять мужу, ничего не знала о планах Ду Хуайляна и не принимала участия в убийстве.

В результате, она была приговорена к удушению за супружескую неверность, а Ду Хуайлян - к отрублению головы. Его приговор был утвержден и приведен в исполнение, а вот госпоже Ли повезло попасть под императорскую амнистию (Hegel, 2009, pp. 79-90).

В обоих приведенных случаях инициатором преступления стал мужчина, потерявший возможность для регулярного внебрачного секса и не желающий с этим смириться. Что до женщин, то их участие в преступлении было очень разным: одна из них, хоть и неохотно, согласилась убить мужа, другая не знала о готовящемся убийстве и даже сама пришла со своими подозрениями в ямынь.

Что действительно впечатляет при чтении этих, как, впрочем, и почти всех судебных дел из китайских архивов, так это чрезвычайная наивность замысла и неискушенность преступников. Оба убийства были преднамеренными, спланированными, они были совершены не в аффекте, и преступники даже предприняли некоторые меры, чтобы избежать разоблачения. При этом ни Дуан Шичжо, ни Ду Хуайлян не задумались о том, что их романы с женами убитых - вовсе не тайна, об этом знают соседи и родственники. Кроме того, совершая убийство и выдавая его за оправданную защиту своей чести, Ду мог бы заранее предвидеть, что судья будет угрожать ему пыткой; а Дуан мог бы догадаться, что отравление мышьяком будет с легкостью диагностировано, и подозрения неизбежно падут на того человека, который приготовил последнюю трапезу жертвы. Однако, как мы уже упомянули, подобная неспособность прогнозировать развитие ситуации встречается едва ли не в каждом деле о предумышленном убийстве, поэтому не следует объяснять ее просто необыкновенной глупостью преступников. Мы скорее склонны считать такую наивность системной и объяснять ее социальным положением убийц. Дело в том, что все эти люди, любовники и любовницы, мужья, жены и соседи, были очень бедны настолько, что Ли Цан был готов выступать сутенером своей жены за продуктовые подарки и кучку медяков. Бедность и неграмотность ограничивали их кругозор и понимание человеческой психологии и следственных процедур. И то, что один из преступников был врачом, не должно обманывать нас, заставляя предполагать, что он был эрудированным специалистом, как современные нам доктора; на самом деле, Дуан Шичжо не получил никакого систематического образования, всю жизнь прожил в родной деревне и научился разбираться в травах от такого же полуграмотного ремесленника, каким стал и сам. Эти люди не читали не только судебных протоколов, но даже и авантюрных 
романов, откуда могли бы почерпнуть какие-то сведения о методах совершения и расследования преступлений.

Между тем, китайская литература содержит множество описаний именно таких убийств. И в этих описаниях есть важное и постоянно повторяемое отличие от только что рассмотренных подлинных дел виноватой стороной здесь всегда назначается женщина.

Наверное, самое знаменитое описание уголовного преступления в китайской классической литературе - это убийство У Далана его женой Пань Цзинь-лянь в великом романе Ши Най-аня «Речные заводи» (предположительно середина XIV в.). Нигде более мы не найдем такого подробного, психологически и ситуативно выверенного анализа всех обстоятельств, приведших к убийству, а также его процесса и последствий. Пань Цзинь-лянь, как рассказывает автор, была служанкой в богатом доме, где ее стал домогаться хозяин, и возненавидела хозяйка, в результате ее наказали, выдав замуж за торговца лепешками У Далана, который был не только беден, но еще и робок нравом и весьма дурен наружностью, от чего красавица Пань Цзинь-лянь очень страдала. Затем к ее мужу вернулся из дальних краев его младший брат - герой У Сун, и невестка сразу же попробовала соблазнить его, что вызвало решительный и гневный отпор со стороны героя. Она стала жаловаться мужу, якобы деверь пристает к ней, но у Далана не хватило решительности поверить ни жене, ни брату. Через некоторое время молодая женщина случайно попалась на глаза местному богачу и распутнику Симынь Циню, который при помощи и посредничестве соседки по фамилии Ван сумел встретиться с красавицей и вступить с ней в связь. Позже, когда У Сун на несколько месяцев отправился в столицу, У Далан вдруг узнал об измене жены, он ворвался в чайную матушки Ван, когда в ее внутренних комнатах Цзинь-лянь принимала любовника. Но он был мал ростом и слаб, и Симынь Цин избил его до полусмерти. После этого любовники поняли, что им несдобровать, когда У Сун вернется и узнает от брата об этом происшествии, и тогда старуха Ван уговорила Симынь Цина и Цзинь-лянь поскорее убить Далана, пока он еще болен. Итак, Симынь Цин раздобыл мышьяк, а женщина напоила этим ядом мужа, а затем еще и задушила его одеялом.

Сначала все шло по их плану: уездного коронера заставили признать причину смерти естественной, труп сожгли. Но У Сун, вернувшись, все равно не поверил в то, что его брат просто умер от сердечного приступа, он добился правды от коронера, и, когда подкупленный начальник ямыня отказался открывать дело об убийстве, У Сун 


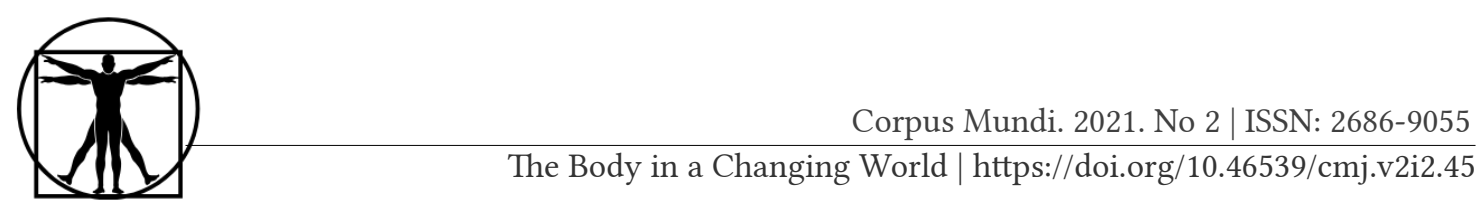

взял месть в свои руки. Он отрезал головы невестке и старухе Ван и до смерти забил Симынь Цина (Ши, 1995, Т.1, сс. 375-417).

Симынь Цин в этих главах, конечно, показан как развратник и негодяй, но главную вину автор все же возлагает на женщин. Живописуя заигрывания Цзинь-лянь с деверем, автор показывает, что причиной последующей трагедии стала не какая-то необыкновенная и подлинная любовь, вспыхнувшая между нею и Симынем, а обычная сексуальная неразборчивость красавицы. И, хотя замысел и план убийства принадлежали не ей, а другой женщине - старой Ван, Пань Цзиньлянь исполнила все задуманное без тени жалости и сомнения.

Подобным же образом расставлены акценты и в другом эпизоде «Речных заводей» - истории начальника тюрем Ян Сюна и его побратима Ши Сю. Ян Сюн каждый день уходил на службу, а его побратим оставался дома, где мог наблюдать за жизнью семьи Яна. И вот он выяснил, что жена Яна по имени Цяо-юнь тайно принимает у себя любовника: ее служанка выставляла из задней калитки столик с горящей свечой, чтобы показать, что этой ночью начальника тюрем нет дома, и тогда к ней в спальню прокрадывался блудливый монах. Однако, когда Ши Сю попытался открыть своему побратиму глаза на творящееся безобразие, тот ему не поверил, потому что жена оклеветала деверя перед мужем, сказав, что Ши Сю приставал к ней. Побратимы расстались, но Ши Сю не забыл своего братского долга, он напал на любовника невестки и убил его возле той самой задней калитки. Тогда Ян Сюн понял, что был неправ, он помирился с братом, вместе он вывезли изменницу и ее пособницу-служанку в горный лес и там подвергли чудовищной казни, буквально разрезав на куски.

Эта история, несколько менее подробная, чем эпизод с Пань Цзиньлянь, не описывает домогательств невестки к деверю или ее покушения на жизнь своего мужа, однако мы вправе предполагать их из внутреннего монолога Ши Сю. Глядя на то, как Цяо-юнь беседует с монахом, он восклицает про себя: «Я уже несколько раз замечал, что эта женщина слишком вольно ведет себя со мной, но относился к ней как к своей сестре. А она, оказывается, просто шлюха!» Будучи же оклеветанным и изгнанным из дома Яна, герой убеждает себя в необходимости продолжать слежку за неверной женой: «Ян Сюн побратался со мной, и если я не выведу обманщицу на чистую воду, то зря погублю его жизнь!» (Ши, 1955, Т. 2, сс. 190-239). Значит, с точки зрения персонажа, так же как и автора и читателей великого романа, сам факт супружеской измены со стороны женщины автоматически влек за собой опасность для жизни ее мужа. 
«Речные заводи» в целом - произведение очень мизогинное, практически все женщины, за исключением двух или трех разбойниц, представлены как воплощение зла. В лучшем случае, они невольно навлекают на мужчин несчастье, но чаще они делают это осознанно и охотно, своей алчностью и наглостью провоцируя бедных жертв на убийства. Так попадает в изгнание протагонист романа Сун Цзян, зарезавший свою распутную наложницу за попытку шантажа (Ши, 1955, Т. 1, сс. 314-341); так попадает в тюрьму офицер ямыня «Летающий тигр» Лэй Хэн, убивший колодкой нахальную певичку Бай Сю-ин за грубость по отношению к его матери (Ши, 1955, Т.1, сс. 298-314); так Сун Цзян лишается возможности вернуться из ссылки домой, потому что жена чиновника Лю Гао, спасенная им ранее из разбойничьего стана, безо всякой причины, просто из присущей ее характеру злобы, обвиняет его самого в связях с разбойниками (Ши, 1955, Т. 1, сс. 484-496, Т. 2, сс. 19-35). Однако, было бы ошибочным полагать, что подобная мизогиния, заставлявшая видеть во всех женщинах развратниц, а во всех преступлениях искать виноватую женщину, проистекает лишь из собственного мировоззрения Ши Най-аня. Другим литературным произведениям старого Китая, возможно, недостает мастерского слога, сочных деталей и откровенной ненависти, присущих «Речным заводям», но общие тенденции в оценке преступлений, их причин и виновников совершенно сходны.

Выдающийся минский прозаик Фэн Мэнлун (1574-1646) в новелле «Трижды оживший Сунь» описывает как писарь ямыня после своего загадочного исчезновения появляется вновь и вновь в виде призрака и просит разобраться с обстоятельствами своей гибели. На это оказывается способен лишь знаменитый судья Бао Драконова Печать, да и то лишь при активной помощи потусторонних сил. Однако в основании всего этого дела лежит не волшебство, а преступление: жена писаря Суня тайно сошлась с его однофамильцем, убила мужа, а затем объявила, что из верности памяти покойного супруга выйдет замуж лишь за человека по фамилии Сунь (Проделки, 1989, сс. 61-80).

В уже упомянутом романе цинского времени «Трое храбрых, пятеро справедливых» убийство любовниками обманутого мужа самое частотное из преступлений, уже в начале романа такой сюжет повторяется трижды, причем один раз, как и в «Речных заводях», изменница успевает оклеветать перед мужем его брата, чтобы последний не разоблачил ее. В середине романа тот же конфликт разыгрывается еще раз, и вновь, как и у Ши Най-аня, завязкой драмы послужили домогательства распутной наложницы богача к нанятому в дом на службу молодому учителю-конфуцианцу. Учитель отверг 


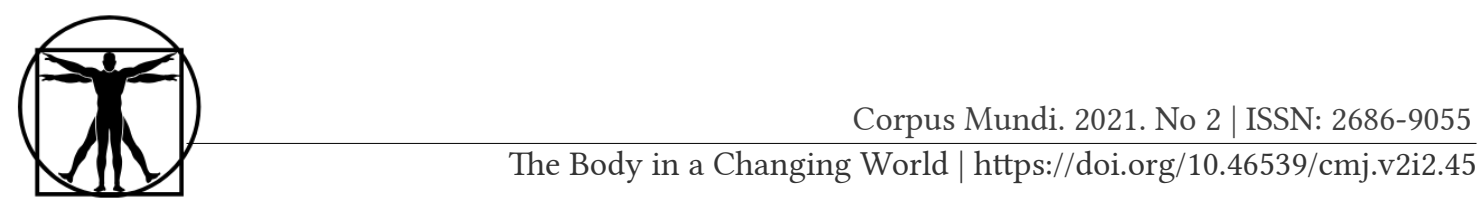

ее притязания, но об этом случайно стало известно мужу женщины, и он в гневе хотел было ее убить, но его остановила его старшая жена, напомнив ему, что убивать наложницу, не застав ее в постели с чужим мужчиной, - это преступление. Тогда супруги решили запереть изменницу в павильоне и не кормить ее, чтобы она умерла от голода. В таких обстоятельствах наложница позвала к себе одного из слуг дома и уговорила его стать ее любовником и ради нее убить хозяина, а вину свалить на хозяйку, чтобы все семейное имущество досталось им (Ши, 1974, сс. 48-75, 236-239).

Во всех этих литературных примерах, в самой их распространенности и своего рода нормативности, виден укорененный в менталитете китайцев страх перед женской сексуальностью и коварством, а также убеждение в том, что неверная жена уничтожает не только и не столько честь своего мужа, сколько само его физическое существование. Анализ судебных протоколов, напротив, не подтверждает предположений о массовости подобного типа преступлений. Тогда чем же следует объяснить этот общественный страх? Мы предполагаем, что это - порождение, во-первых, мизогинной идеологии, во-вторых же, распространенного семейного насилия, когда муж, бьющий или иными способами тиранящий жену, начинает втайне опасаться мести с ее стороны, а патриархатное сознание, не в силах возложить хотя бы частичную ответственность за эту месть на того, кто развязал насилие, предпочитает считать мотивом для действий женщины ее моральные недостатки - похоть и злобу.

\section{СЕКСУАЛЬНЫЕ ДОМОГАТЕЛЬСТВА, ИЗНАСИЛОВАНИЯ, МЕСТЬ ЗА СЕКСУАЛЬНЫЕ ПРЕСТУПЛЕНИЯ}

На практике моральный облик женщины становился объектом самого пристального изучения в делах о сексуальном насилии. По сути дела, все подобные дела сосредотачивались на личности жертвы, пытаясь определить ее истинные намерения. Согласно цинскому законодательству сексуальный акт мог быть квалифицирован как изнасилование только в том случае, если жертва кричала и сопротивлялась от начала до конца, невзирая на бессмысленность сопротивления и на угрозу быть убитой; если же она активно сопротивлялась только в начале, а затем замолкала и прекращала бороться, то суд называл это «действие, начавшееся как изнасилование, но закончившееся как незаконное сожительство». Считалось вообще чрезвычайно важным выяснить подлинный умысел жертвы, поэтому в помощь судьям выпускались целые пособия по проведению допросов, самым 
известным из которых стало руководство опытного судьи Хуан Люхуна «Полная книга о счастье и благоденствии» (1696 г.). Там, в частности, говорилось, что женщина, подвергнувшаяся насилию, не может сдерживать своего гнева и кричит, обличая насильника, несколько не заботясь о своей репутации, если же она не может смотреть обвиняемому в лицо, стыдится, говорит тихо и сбивчиво - значит, никакого изнасилования не было, и имеет место либо оговор, либо незаконная связь с согласия обеих сторон (Huang, 2006, pp. 429, 435). На этом стереотипном поведенческом анализе был построен сюжет рассказа великого цинского писателя Пу Сун-лина (1640-1715), непревзойденного мастера короткой новеллы, под названием «Тайюаньское дело». В нем выведены невестка и свекровь, утверждавшие, что их изнасиловал один и тот же мужчина, но мудрый судья догадывался, что лишь одна из них была, и вправду, жертвой преступления, а другая - тайной любовницей злодея. Но как выяснить, кто есть кто? И тогда судья приказал им убить насильника своими руками. «Невестка, давно таившая к этому человеку ненависть, обеими руками схватила огромную кирпичину и жалела, повидимому, только о том, что не убила его одним ударом. Свекровь же брала лишь мелкие камешки: бросит ему в ляжку или ягодицу - только и всего. Тогда правитель велел им взять по ножу. Свекровь опять замялась. Правитель остановил их. - Я знаю, - сказал он, - кто из вас блудница! И велел задержать свекровь, наложив на нее жестокие колодки» (Пу, 2000, с. 697).

Гораздо более глубокое понимание психологии жертвы цинский закон проявляет в делах о сексуальном харассменте. В подобных случаях пострадавшую женщину тоже, конечно, спрашивали, в каких отношениях она состояла с обвиняемым, не давала ли она ему оснований считать себя доступной, и как вообе случилось, что она осталась наедине с чужим мужчиной. Но требуемое конфуцианскими нормами приличия строгое разделение полов было возможно только в очень богатых семьях, а основная масса китаянок была вынуждена участвовать в производительном труде и так или иначе контактировать с посторонними, судьи это знали, и как правило, в ответ на такие вопросы жертве домогательств было достаточно сослаться на свою бедность. Зато закон очень серьезно относился к репутационным потерям женщины в результате домогательств, к ее попранному чувству собственного достоинства и особенно - к угрозе ее самоубийства в случае, если ее обида никак не будет отомщена.

Еще в минское время, в 1588 г., был принят закон, который в очень общих выражениях требовал наказывать за доведение человека до самоубийства в связи с незаконными сексуальными отношениями. 


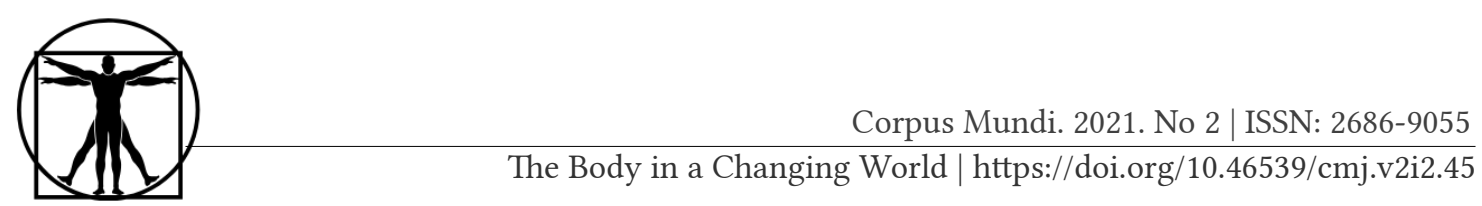

А начиная с 1733 г. были в короткий срок приняты 16 законов, уточняющих различные аспекты доведения до самоубийства, двенадцать из них были посвящены самоубийствам в результате изнасилования, покушения на изнасилование, «нежелательных предложений», «непристойной фамильярности», «грязных шуток» и «неприличных жестов». Если жертва харассмента убивала себя, то ее оскорбитель должен был подвергнуться смертной казни, а сами женщины, покончившие с собой при подобных обстоятельствах, прославлялись как мученицы и образцы целомудрия, им за государственный счет сооружались поминальные арки в их родных поселениях или ставились таблички в местных храмах. Может создаться впечатление, что правительство, таким образом, подталкивало женщин к самоубийству. Но, даже если такое и случалось помимо воли самих администраторов, то они в то же время заботились и об уменьшении числа таких суицидов. В 1745 г. высокопоставленный столичный чиновник Чжан Жоай подал меморандум на высочайшее имя, в котором указывал, что женщины, судя по документам, присылаемым из провинций, нередко кончают с собой спустя несколько дней, или даже недель после перенесенного оскорбления. С точки зрения автора меморандума, это означало, что все это время они ждали восстановления справедливости и наказания обидчика, то есть их гибель возможно было бы предотвратить, если бы главы семей и деревень вовремя сообщали о преступлениях в ямынь, а начальники ямыней вовремя предпринимали необходимые меры. Чжан предложил карать домогательства ношением канги: «Таким образом, гнев и унижение женщины будут утолены, а обидчик сможет избежать необходимости платить за свою вину жизнью» (Theiss, 2004, pp. 51-52). Результатом этого доклада стало принятие закона, по которому родня женщины наказывалась 80 ударами палки в случае, если они не донесли об оскорблении, и жертва в результате покончила с собой. Эдикт 1759 г. велел чиновникам довести до сведения народа, как следует поступать, если женщина подверглась домогательствам: «...семьи и родственники должны стараться утешить (жертву А.С.) и не усиливать ее чувство унижения. Если (она - А.С.) изначально не намеревалась умирать, то тем более, они не должны обвинять ее или заставлять отнимать свою жизнь» (Theiss, 2004, p. 53).

Из этих указов и законов делается понятно, что государство рассматривало семью пострадавшей женщины скорее как ее врагов, и ожидало от них укрывательства ее обидчика и жестокости по отношению к самой женщине - вплоть до подталкивания ее к самоубийству, чтобы тем загладить семейное бесчестие. И опыт показывает, что 
такое предубеждение против семейного коллектива иногда было вполне оправданным.

Так, в 1752 г. большая семья народности мяо оказалась расколота конфликтом, когда девятнадцатилетняя Ван Агуань в поле подверглась нападению своего двоюродного брата Ван Али. Она стала отбиваться, и на ее крики пришел ханец с соседнего поля и проводил ее домой. Там она пожаловалась своим старшим брату и сестре, и они на следующий день отправились к Али и его отцу требовать извинений. Их требования были вполне умеренными: чтобы виновник пришел к ним в дом и, кланяясь до земли, просил прощения. Но отец Али сперва наотрез отказался даже обсуждать случившееся, на следующий же день заявил, что Агуань клевещет, потому что поссорилась с его сыном из-за воды для полива полей, и вообще она - «чудовище без чести». Не выдержав таких обвинений, Агуань повесилась, и только тогда ее близкие сообщили о происшествии в ямынь (Theiss, 2004, pp. 18-19). Разумеется, упреки в лживости и бесчестии звучат из уст отца насильника, то есть человека крайне заинтересованного в его оправдании, и следовательно, не могут представлять мнение всей семьи, но стоит заметить, что и брат и сестра жертвы тоже не торопятся пожаловаться на кузена в ямынь, и считают один земной поклон достаточным наказанием за попытку изнасилования.

Женщины-жертвы, как подчеркивает Дженет Тейсс, в большинстве случаев настаивали на судебном разбирательстве, а вот их родственники предпочитали скрывать случаи изнасилований и домогательств, называя это «позорными делами», о которых лучше никому не говорить (Theiss, 2004, p. 13). Очевидно, здесь к страху перед долгим судебным рассмотрением, перед возможным тюремным заточением свидетелей и пытками подозреваемых, перед произволом судей и палками для всех причастных и непричастных добавлялся страх позора. Причем, речь идет о позоре для всей семьи, а не только женщины. В ранее упомянутом эпизоде с женой начальника тюрем Ши Най-ань вкладывает очень характерное объяснение в уста женщины, когда она лжет мужу о том, как к ней якобы домогался деверь, прикасаясь к ее груди: «Я ударила его по руке и хотела было закричать, но потом побоялась, что услышат соседи, и это будет позором для тебя» (Ши, 1955, T.2, c. 229).

В таком случае, почему же женщины не боялись обращаться в ямынь? Согласно закону, женщин в суде не пытали, но там им приходилось доказывать свою порядочность и во всеуслышание рассказывать о пережитом харассменте или даже насилии, поэтому им нужны были весьма серьезные причины, чтобы пренебречь гордостью и стыдливо- 


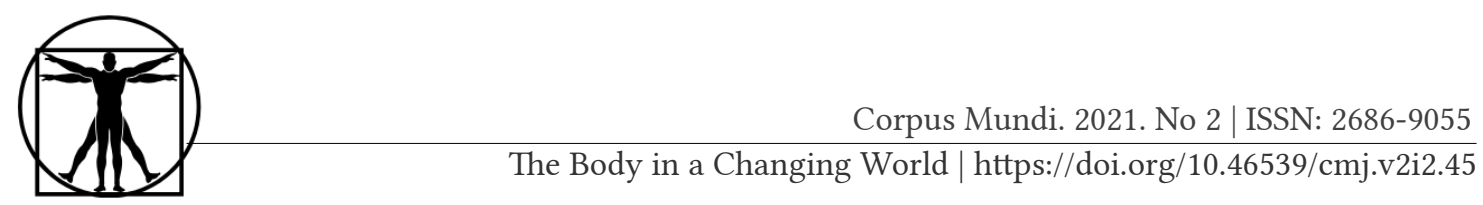

стью и пойти на судебное разбирательство. Источники не дают прямого ответа на вопрос об этих причинах, так что нам остается лишь строить предположения: вероятно, только государственное вмешательство могло, во-первых, наложить на преступника достаточно тяжелое наказание там, где клан ограничился бы порицанием с последующим принудительным примирением сторон, во-вторых, предоставить женщине трибуну для публичного восстановления своей чести. Если она могла в ямыне, в процессе унизительного допроса, доказать, что она была чиста и ничем не провоцировала насильника, то в дальнейшем ни муж, ни родня, ни соседи не могли уже вновь поставить ей это в вину. Если же такой возможности ее лишали, то впоследствии всякий мог усомниться в ее порядочности, что было равносильно социальной смерти. А в условиях патриархального клана социальная смерть очень быстро могла повлечь за собой и физическую, как об этом рассказывает, например, повесть Фэн Мэнлуна «Сожжение храма Драгоценного Лотоса».

В повести рассказывается о монастыре, про который говорили, что в нем будды и бодисатвы посылают бесплодным женщинам детей, и стоило паломнице переночевать в закрытой келье этого монастыря, как вскоре она беременела. На самом деле, в закрытые кельи вели тайные ходы, по которым туда проникали ночью монахи и насиловали богомолок. Мудрый уездный начальник догадался, что здесь дело нечисто, и сумел с помощью хитрости разоблачить обман. Когда же монахи были арестованы и казнены, монастырь сожжен, и народ узнал, что там происходило, то хуже всех пришлось жертвам изнасилований: «Мужья не признали рожденных ими детей за своих наследников, многие выгнали жен из дома, а младенцев предали смерти путем утопления. Некоторые женщины, не стерпев позора, приняли добровольную смерть. Нравы этих мест заметно улучшились» (Проделки, 1989, cc. 155-177).

Итак, изнасилование или домогательство к женщине наносило бесчестие не только ей самой, но и всей ее семье, или, по меньшей мере, - ее мужу и братьям. Если женщина могла смыть бесчестие в суде, а мужчины старались суда избегать, то что же оставалось им делать, чтобы восстановить свое самоуважение? Зачастую в такой ситуации они прибегали к насилию, даже если оно было направлено против близких родственников.

Так, в одном случае в Нинъюане провинции Ганьсу деревенский староста увидел женщину, урожденную Ван, стоявшую над высоким обрывом, и сразу догадался, что она собирается покончить с собой. Он сумел вовремя остановить ее и расспросил о причинах. Оказа- 
лось, что, пока муж госпожи Ван странствует в поисках заработка по чужим краям, ее вдовый свекр не оставляет попыток изнасиловать ее и жестоко бьет за сопротивление. Староста проводил женщину в соседнюю деревню, к ее брату, и рассказал ему обо всем, что узнал. Брат урожденной Ван позвал на помощь своего зятя, мужа еще одной своей сестры, и вдвоем они отправились в дом к свекру-насильнику, чтобы, как они сами потом объясняли, «наказать» его, из чего не совсем понятно, имели ли они намерение убить старика. Ворвавшись прямо в его спальню, брат жертвы закричал: «Ты свекр, и все-таки совершаешь такое бесчестное дело! Как ты можешь еще называться человеком!», и затем они задушили его. Староста, сочувствовавший убийцам, был готов признать смерть естественной, но коронер, который должен был осмотреть тело перед тем, как выдать разрешение на погребение, усомнился в этом и доложил в управу. В результате убийц судили и приговорили к удушению, а урожденная Ван, хотя она не участвовала в убийстве и не знала о нем заранее, была приговорена к сотне ударов тяжелой бамбуковой палкой и штраффу за сокрытие убийства старшего в семье (Theiss, 2004, p. 114).

В другом интересном случае, произошедшем в Чжэцзяне, некий Ма Третий терроризировал женщин всей деревни, включая и двух своих невесток. Одну из них, недавно оставшуюся вдовой, он попытался изнасиловать, и хотя она сумела дать ему отпор, но поняла, что ее единственный способ выжить и сохранить честь - поскорее выйти замуж снова и уехать. Тем не менее, ей пришлось оставить в доме Ма своего старшего сына. Тогда Ма Третий переключил свое внимание на младшую невестку, чей муж, Ма Шестой, часто отсутствовал, потому что торговал в разнос паровыми пельменями. Он накинулся на нее во дворе, который братья делили друг с другом, ей удалось вырваться и убежать из дома, зовя соседей на помощь, но он погнался за ней и избил ее прямо при соседях. Когда Шестой вернулся домой, жена пожаловалась ему на деверя и стала просить его переехать куда-нибудь, но у них не было денег на съем жилья, и Ма Шестой понадеялся, что его брат после публичного скандала постесняется продолжить свои домогательства.

Вместо этого Ма Третий напился пьяным и снова напал на невестку, разорвав даже ее нижнее белье. К счастью, муж вернулся вовремя и прогнал его, но насильник все не унимался - он вернулся в дом к брату, когда супруги обедали, бросил деревянным ведром в голову Шестого, а невестку попытался ударить лопатой. Завязалась драка, и в конце концов Ма Шестой завладел лопатой и нанес ею смертельный удар своему старшему брату. На допросе он так описывал отча- 


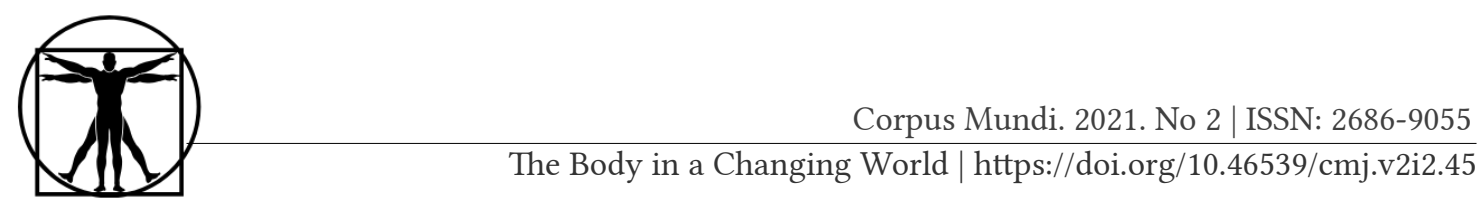

янное положение, в котором оказался: «Если он умрет, и это будет обнаружено, то я заплачу за это собственной жизнью. Мой старший брат был таким злобным хулиганом, что, если бы он очнулся, он бы стал мстить. В любом случае, мне и моей жене трудно было бы избежать смерти». Он решил связать Третьего, но в эту минуту тот умер. Тогда Ма Шестой дождался ночи и с помощью своего племянника, сына невестки, вынужденной повторно выйти замуж, оттащил тело к пруду, привязал к нему камень и утопил его. Тело, однако, всплыло, и происшествие скрыть не удалось.

Местный уездный начальник приговорил Ма Шестого к медленному срезанию мяса с костей за преднамеренное убийство старшего родственника, а его жену - к ста ударам палкой и штрафу за то, что она подняла руку на старшего родственника своего мужа. Но одновременно он рекомендовал столичной Палате наказаний и Трем управам принять во внимание инцестуальные покушения Ма Третьего и снизить степень наказания. Они, тем не менее, не встали на эту точку зрения и сохранили изначальный приговор в силе: «Хотя постоянные попытки Ма Третьего изнасиловать жену своего младшего брата были распущенным и порочным нарушением всех человеческих связей, но Ма Шестой убил старшего брата. Это вопрос правильных взаимоотношений, и здесь закон не может быть снисходительным». В конце концов, в дело вмешался лично император Цяньлун, у которого, судя по его эдиктам, было иное понимание правильных взаимоотношений - он верил в особую значимость брачных уз и ставил их выше поколенческой иерархии. Он отменил постановление столичных судебных инстанций и смягчил приговор Ма Шестому до отрубления головы (Theiss, 2004, pp. 114-115).

В обоих изложенных случаях ближайшие родственники жертвы оказывались на ее стороне, безоговорочно верили ей и были готовы ее защищать. И тем не менее, характерно, что ни Ван, ни Ма даже не попытались защитить своих женщин самым безопасным для себя законным путем, и это при том, что в отношении их сестры и жены совершалось уголовное преступление. Вместо этого они предпочли пойти на конфронтацию с насильниками с риском убить или быть убитыми. И это еще раз показывает тот страх, с которым простой народ старого Китая относился к властям, и их упорное нежелание допускать государство до контроля и регуляции тонких внутренних связей в семейном организме. Как бы чиновники не радели о «правильных взаимоотношениях» в семье, простые люди, «сыновья и младшие братья», не готовы были смотреть на них как на «отцов и матерей народа». 
В завершение мы хотели бы привести еще один пример, в котором, как в капле воды, отразился едва ли не весь комплекс проблем и аттитюдов, типичный для цинского семейного коллектива, столкнувшегося с преступлением в своих рядах. Кроме того, в протоколах этого дела сохранилась неотредактированная живая речь свидетелей и обвиняемых, что дает нам возможность оценить их эмоции и убеждения.

В одной деревне в провинции Цзянси в главном зале храма предков собрались пять человек, это были главы кланового объединения (по своему положению и функционалу их было бы удобно называть старейшинами клана, если бы не тот факт, что старшему из них было всего 45, а младшему - 21 год). Они встретились по вполне мирному поводу - чтобы обсудить размер взносов на проведение жертвоприношения предкам в день зимнего солнцестояния, когда вдруг их совещание прервали крики из близлежащего дома, который как раз принадлежал одному из них, по имени Чжань Чэнсю, а кричала его невестка, урожденная Сю. Главы клана кинулись туда, и взволнованная женщина рассказала им, что она уходила к соседям, оставив дома свою юную дочь Хэйин, и в этот момент к ним в дом вошел племянник ее мужа, Чжань Эрде. Увидев, что девушка дома одна, он попытался ее изнасиловать и порвал ее одежду. Она кричала и сопротивлялась, и на крик прибежала ее мать. Это спугнуло Эрде, и он убежал. Позже Чжань Чэнсю так рассказывал о реакции глав клана: «Когда мы услышали, что произошло такое дело, погубившее репутацию нашей семьи, мы сочли это неприемлемым, и все пошли в дом Чжань Эрде, чтобы схватить его и отвести в храм предков для наказания».

Услышав, что его ищут главы клана, Эрде испугался и сбежал, а его отцу по имени Чжань Чжэнши, главы заявили: «Если ты не можешь контролировать своего сына, тогда, в соответствии с установлениями храма предков, ты должен зарезать свинью и раздать мясо, и в знак раскаяния принести зерно в жертву в храме предков». Чжань Чжэнши предпочел, как и его сын, сбежать из деревни и отправиться к родне своей жены, чтобы переждать всплеск коллективного гнева. Тогда главы рода сами зарезали его свинью и поделили мясо между собой, а также конфисковали из его амбара 20 ши (т.е. примерно 60 ведер) зерна и сложили его в храме. С их точки зрения, это был не грабеж, а справедливое наказание: «Такова старая традиция нашей деревни. Bcex, кто творит беззаконие, наказывают, чтобы предупреждать такие поступки в будущем. Это точно не было грабежом».

С такой конфискацией не смог смириться сам виновник скандала, молодой Эрде: «Я не мог вынести этого, а кроме того, боялся, что люди 


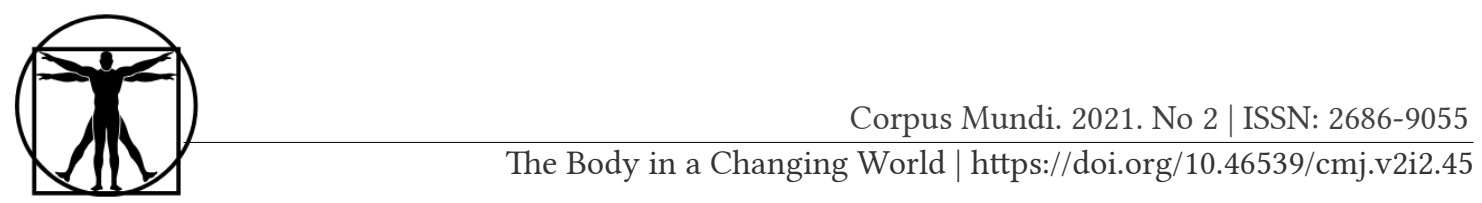

моего клана не согласятся на том и покончить дело, и мне все равно придется получить наказание от ямыня». И тогда он решил сработать на опережение, а заодно отомстить суровым старейшинам. Он убил своего младшего брата-инвалида и, прибежав в дом своей родни с материнской стороны, где как раз укрывался его отец, обвинил в этом злодеянии глав клана и позвал материнскую родню вместе пойти в ямынь и принести жалобу. Но, поскольку он был перепачкан кровью, родственники не поверили в его версию событий и отказались. Он тогда отправился в ямынь один, но был быстро разоблачен на допросе.

Интересно, что помимо Чжань Эрде, виновного в попытке изнасилования и в убийстве, наказание получили и все главы клана: Чжань Чэнсю подвергся 80 ударам палкой как инициатор конфискации зерна и мяса, все остальные - по 60 как его сообщники, кроме того, их обязали возместить ущерб отцу убийцы (Theiss, 2004, pp. 77-78).

В деле семьи Чжань очень выпукло видно свойственное простонародью отношение к властям - в диапазоне от спокойного избегания до ужаса. Если Чжань Эрде так боится ямыня, что под конец в отчаянии решается взять это чудовище в союзники, то Чжань Чэнсю и его товарищи просто не нуждаются в помощи чиновников, будучи уверены в достаточности своей собственной власти.

Здесь мы наблюдаем другой, отличный от физического насилия, способ китайских мужчин восстановить свою честь и защитить своих женщин. Храм предков в рамках этого мышления выступает как достойная альтернатива ямыню; главы клана демонстрируют конфликтный менеджмент, характерный для догосударственных родовых или соседских общин. Во-первых, пострадавшей стороной они считают не девушку Хэйин (ее вообще не упоминают ни разу), а весь семейный коллектив, чья честь и репутация оказались опорочены. Недаром они, с полной уверенностью в справедливости своих решений, реквизируют зерно из хозяйства преступника на нужды всей деревни, а мясо и вовсе делят между собой пятерыми, ведь если рана нанесена телу клана, то и правом на компенсацию пользуются все члены клана, начиная с его старейшин.

Во-вторых, ответчиком за преступления индивида в рамках такого менталитета является вся семья преступника. Если же, как в данном случае, обиженной стороной тоже выступает вся семья, то нести ответственность за преступление община предлагает непосредственной ближайшей родне злодея. Тогда как ямынь присудил бы к ношению канги или битью палками лично Эрде, клан обращает основное свое наказание на его отца, разоряя его хлев и амбар. 
B-третьих, целью наказания здесь является не собственно восстановление справедливости, не страдания виновника, а профилактика подобных деяний в будущем, плюс погашение конфликта. По сути дела, это не суд, а медиация, в которой на нарушителя спокойствия накладывается ровно та мера взыскания, которая успокоит пострадавшую сторону, «даст ей лицо» и позволит ей и дальше жить в одной общине с обидчиком, но не более, поэтому, как правило, в догосударственных коллективах основным наказанием за все нарушения служит вира.

Трудно сказать, понимали ли уездные чиновники этот вызов их власти со стороны кланового объединения, или просто карали их за самосуд и недонесение, способное довести пострадавшую женщину до самоубийства.

\section{ЗАКЛЮЧЕНИЕ}

Итак, из рассмотрения подлинных судебных дел цинского периода, касающихся внутрисемейных преступлений, и их сопоставления с художественной литературой того же и немного более раннего времени, можно сделать несколько выводов. Во-первых, обращает на себя внимание выраженный страх и нежелание простого народа выносить свои семейные дела на суд управы. В этом страхе присутствует как рациональный компонент, то есть боязнь перед суровыми допросами и пытками, перед длительным тюремным заточением, что означало также длительный простой в трудовой деятельности, перед непредсказуемыми карами за все, включая неспособность предотвратить чужие поступки; так и репутационные моменты, связанные с нежеланием публично обсуждать секреты своей семьи. Кроме того, крестьяне-общинники были зачастую уверены, что могут и сами оказать достаточное давление на своих оступившихся соседей и родичей, и завершить конфликт примирением сторон.

Интересно также и гендерное различие мнений по вопросу о желательности государственного вмешательства в семейные противоречия. Тогда как мужчины практически всегда были против такого внешнего вмешательства, женщины выступали за него в тех случаях, когда под угрозой оказывалась их честь. Став жертвой изнасилования или посягательства, женщина предпочитала опереться на государство как постороннюю и более могущественную по отношению к ее клану силу, так как чувствовала, что не имеет влияния на процесс принятия решений патриархами клана, и что ее честью и жизнью могут пожертвовать ради мира и спокойствия в семье. Семья, как мы видели, 


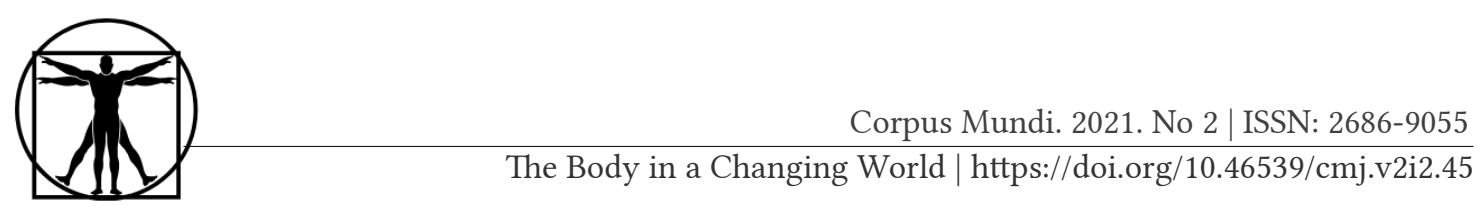

вообще не рассматривала саму женщину как потерпевшую, тогда как государство в полной мере признавало субъектность женщины. Государство, с одной стороны, возлагало на нее непропорционально большую ответственность за то, как с нею обходятся другие люди, с другой же - объявляло ее телесную целостность, ее достоинство и репутацию высокой ценностью, подлежащей защите.

Сердцевиной и ценностным стержнем массового сознания китайцев, как преступников, так и чиновников и писателей, продолжала оставаться сыновняя почтительность 孝 (хіао). Убийцы в свое оправдание ссылались на то, что потерпевшие, якобы, нанесли какую-то обиду их родителям (Theiss, 2004, p. 85); судьи могли существенно смягчить наказание преступнику ради заботы о престарелых или жертвоприношений покойным родителям. Так же тверды были позиции и прочих конфуцианских идей, в частности, сохранялся акцент на нравственном воспитании как важнейшем способе упорядочивания космоса и социума; и потому моральные недостатки личности виделись как единственная причина преступности. Следовательно, сознание народа полностью игнорировало социальные причины, не учитывая таких факторов как бедность, социальное неравенство, семейное насилие. И так же, вслед за Конфуцием, ставившим знак равенства между женщинами и «ничтожными людишками» в противопоставление «благородному мужу» (Конфуций, 2007, с. 115), в народном сознании цвела мизогиния: литература живописала нахалок, провоцирующих мужей убить их, и изменниц, которые сами, в свою очередь, покушались убить своих мужей и ссорили их с их братьями. А суд всегда был настороже, чтобы не дать распутницам себя обмануть; любопытно, что даже изнасилование считалось опасным именно потому, что подталкивало женщин (а не мужчин! - А.С.) к разврату, как это пояснял Хуан Люхун в своем пособии по проведению допросов: «Смертный приговор насильнику - это способ защитить добродетель целомудрия и предотвратить женскую распущенность» (Huang, 2006, p. 432).

Впрочем, в цинское время конфуцианская идеология понемногу переставала быть той монолитной твердыней, какой она стала на протяжении всего предшествующего позднеимперского периода, - один из важнейших государственных институтов последовательно и планомерно снижал значимость сыновней почтительности и поколенческой иерархии вообще. И не считаться с этим институтом было невозможно, так как это был собственно император Великой Цин. Как мы уже видели при анализе законов и отдельных судебных протоколов, цинские императоры своими эдиктами сознательно ограничивали права патриархальных кланов и в противовес им подчеркивали значимость брачных 
уз, прославляли женское целомудрие и супружескую верность как подвиг перед государством, и всегда были готовы вмешаться в отправление правосудия, чтобы смягчить приговор нарушителю поколенческой иерархии и защитнику нуклеарной семьи.

Это на первый взгляд кажется парадоксальным, учитывая, что император воспринимался как патриархальный глава супер-клана. Разрешение данного противоречия мы видим в альтернативном понимании взаимоотношений государя и подданных, которое тоже существовало в конфуцианской мысли. В работах идеологов неоконфуцианства, то есть той официально одобренной версии конфуцианства, которая возникла во времена династии Сун (960-1279 гг.) и стала господствующим направлением китайской философии в целом, наряду с уподоблением государя отцу, а подданного - сыну, встречается и другая аналогия: государь сравнивается с мужем, а министр - с женой. Как девушка обладала свободой выйти замуж за того, кого выберет, или же не выходить вообще, так и образованный человек мог выбирать, служить ли ему, или оставаться свободным, и какому государю служить. Но раз выйдя замуж, женщина навеки связывала себя со своим избранником, обязана была ему полным повиновением, не могла от него уйти по собственной воле, сохраняла ему верность даже после его смерти. Аналогично и от человека, принявшего должность и получающего государственное жалованье, ожидалась беспредельная лояльность монарху (Feng, 2006, p. 444). Возможно, цинские императоры тяготели именно к такому пониманию своих родственных взаимоотношений с империей, распространяя его уже не только на министров и чиновников, но и на все население Китая. Маньчжуры, управлявшие народом, состоявшим в подавляющем большинстве из ханьцев, могли не ощущать своей генетической связи с этим народом, и для них логично было бы смотреть на себя как на супругов, а не отцов своих подданных. Таким образом, незыблемость брачного союза приобретала поистине политическое значение, а попытки встать между мужем и женой становились прелюдией к мятежу.

На оперативный уровень этот эмоциональный и интеллектуальный посыл сверху спускался в виде ослабления внимания к поколенческим статусам преступника и жертвы. Степень вины все в меньшей мере зависела от того, кто из них принадлежал к старшему поколению, и все в большей мере - от наличия умысла на совершение преступления и от причины, побудившей преступника нарушить закон.

И тело семейного коллектива, и тело «государства-семьи» в цинском Китае, таким образом, проявляли замечательную устойчивость и стремление сохранять прежние, тысячелетиями существо- 
вавшие формы, но при этом внутри этого сложного организма протекали медленные, едва заметные глазу процессы развития и качественного изменения.

\section{Список литературы}

Ames, R. T. (1994). The Art of Rulership. A Study of Ancient Chinese Political Thought. Albany: State University of New York Press.

Feng, Y. (2006). Philosophy at the Basis of Traditional Chinese Society. In Browning, D. S., Green, M. C. \& Witte-Jr., J. (Eds.). Sex, Marriage and Family in World Religions (pp. 441-448). NY: Columbia University Press.

Hegel, R.A . (Ed.). (2009). True Crimes in Eighteenth-Century China. Twenty Case Histories. Seattle: University of Washington Press.

Huang, L.H. (2006). Fuhui quanshu. A Complete Book Concerning Happiness and Benevolence. In Browning, D. S., Green, M. C. \& Witte-Jr., J. (Eds.). Sex, Marriage and Family in World Religions (pp. 431-443). NY: Columbia University Press.

Kutcher, N. (1999). Mourning in Late Imperial China: Filial Piety and the State. NY: Cambridge University Press.

Li, J. \& Wang, Y. (Eds.). (2014). An Introduction to Chinese Classics: Confucianism, Taoism, Buddhism. Nanjing: Jiangsu People's Publishing House.

Theiss, J. M. (2004). "Disgraceful Matters”. The Politics of Chastity in Eighteenth-Century China. Berkley, Los-Angeles, London: University of California Press.

Twitchett, D. \& Fairbank, J. K. (Eds.). (2008). The Cambridge History of China. (Vol. 1). Cambridge: Cambridge University Press.

Конфуций. (2007). Луньюй. М: Эксмо.

Проделки Праздного Дракона: Двадизать пять повестей XVI-XVII вв. (1989). М: Художественная литература.

Пу, Сун-лин.( 2000). Странные истории из Кабинета Неудачника. СПб: Петербургское Востоковедение.

Ши, Най-ань. (1955). Речные заводи. (Т.1-2). М: Художественная литература.

Ши, Юй-кунь. (1974). Трое храбрых, пятеро справедливых. М: Художественная литература.

\section{References}

Ames, R. T. (1994). The Art of Rulership. A Study of Ancient Chinese Political Thought. Albany: State University of New York Press.

Feng, Y. (2006). Philosophy at the Basis of Traditional Chinese Society. In Browning, D. S., Green, M. C. \& Witte-Jr., J. (Eds.). Sex, Marriage and Family in World Religions (pp. 441-448). NY: Columbia University Press.

Hegel, R. A. (Ed.). (2009). True Crimes in Eighteenth-Century China. Twenty Case Histories. Seattle: University of Washington Press. 
Huang, L. H. (2006). Fuhui quanshu. A Complete Book Concerning Happiness and Benevolence. In Browning, D. S., Green, M. C. \& Witte-Jr., J. (Eds.). Sex, Marriage and Family in World Religions (pp. 431-443). NY: Columbia University Press.

Kutcher, N. (1999). Mourning in Late Imperial China: Filial Piety and the State. NY: Cambridge University Press.

Li, J. \& Wang, Y. (Eds.). (2014). An Introduction to Chinese Classics: Confucianism, Taoism, Buddhism. Nanjing: Jiangsu People's Publishing House.

Theiss, J. M. (2004). “Disgraceful Matters”. The Politics of Chastity in Eighteenth-Century China. Berkley, Los-Angeles, London: University of California Press.

Twitchett, D. \& Fairbank, J. K. (Eds.). (2008). The Cambridge History of China. (Vol. 1). Cambridge: Cambridge University Press.

Confucius. (2007). Analects. Moscow: Exmo. (In Russian).

Idle Dragon's Tricks: Twenty-fiveshort stories of XVI-XVII centuries. (1989). Moscow: Khudozhestvennaya literatura. (In Russian).

Pu, Songling.( 2000). Strange Tales from a Chinese Studio. Saint Petersburg: Peterburgskoye Vostokovedenie. (In Russian).

Shi, Naian. (1955). Water Margins. (Vol.1-2). Moscow: Khudozhestvennaya literatura. (In Russian).

Shi, Yukun. (1974). The Seven Heroes and Five Gallants. Moscow: Khudozhestvennaya literatura. (In Russian). 